\title{
Barrier-Island and Estuarine-Wetland Physical-Change Assessment after Hurricane Sandy
}

By Nathaniel G. Plant, Kathryn E.L. Smith, Davina L. Passeri, Christopher G. Smith, and Julie C. Bernier

Open-File Report 2017-1157

U.S. Department of the Interior

U.S. Geological Survey 


\section{U.S. Department of the Interior \\ RYAN K. ZINKE, Secretary}

\section{U.S. Geological Survey \\ William H. Werkheiser, Deputy Director \\ exercising the authority of the Director}

U.S. Geological Survey, Reston, Virginia: 2018

For more information on the USGS-the Federal source for science about the Earth,

its natural and living resources, natural hazards, and the environment-visit

https://www.usgs.gov/ or call 1-888-ASK-USGS (1-888-275-8747).

For an overview of USGS information products, including maps, imagery, and publications, visit https://store.usgs.gov/.

Any use of trade, firm, or product names is for descriptive purposes only and does not imply endorsement by the U.S. Government.

Although this information product, for the most part, is in the public domain, it also may contain copyrighted materials as noted in the text. Permission to reproduce copyrighted items must be secured from the copyright owner.

Suggested citation:

Plant, N.G., Smith, K.E.L., Passeri, D.L., Smith, C.G., and Bernier, J.C., 2018, Barrier-island and estuarinewetland physical-change assessment after Hurricane Sandy: U.S. Geological Survey Open-File Report 20171157, 36 p., https://doi.org/10.3133/ofr20171157.

ISSN 2331-1258 (online) 


\section{Acknowledgments}

This report presents interpretations of data collected with the assistance and guidance from a number of Federal land managers, including Kevin Holcomb, Virginia Rettig, and Paul Castelli from the U.S. Fish \& Wildlife Service, and Neil Winn and Bill Hulslander from the National Park Service. We thank them for their interest and input to our research efforts.

This report summarizes and synthesizes work conducted by a wide range of U.S. Geological Survey (USGS) staff who collected and analyzed data, developed work plans, and administered complicated contracts to produce a broad range of products. The report authors acknowledge the following USGS staff: John Barras, Elisha Ellis, Catherine Wheaton, Scott Adams, Arnell Forde, Kristy Guy, Marci Marot, Bruce Richmond, James Bishop, Brent Lunghino, Haunani Kane, SeanPaul La Selle, Bruce Jaffe, Joseph Terrano, Steven Douglass, Danielle Swiderski, Nick Zaremba, Kara Doran, Hilary Stockdon, Karen Morgan, Neil Ganju, Zafer Defne, David Nagle, Ellen Raabe, Rudy Troche, Teresa Bellino, Laura Bricker, Joe Carroll, Sandy Coffman, Mark Hansen, Cheryl Hapke, Patti Hartsing, Susan Helmer, Lisa Morrow, Dick Poore, Susan-Russel Robinson, and Rob Wertz. We thank Neil Ganju and Hilary Stockdon for their critical review of the first draft; their suggestions led to revisions that improved the clarity of this report. Betsy Boynton, Heather Schreppel, and Marilyn A. Billone supported the review, editing, and publication process. 


\section{Contents}

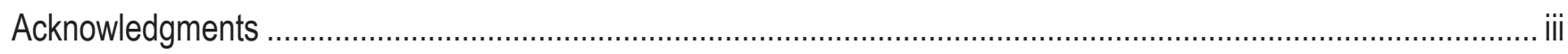

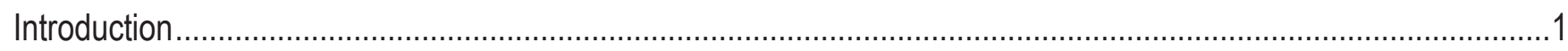

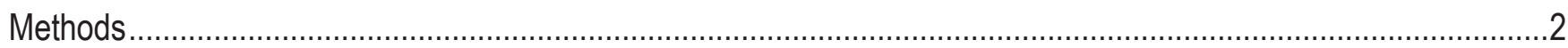

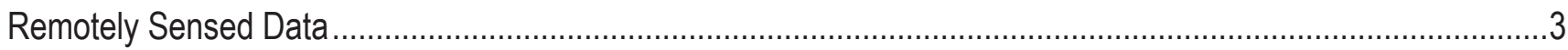

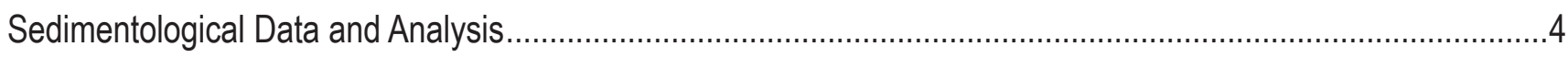

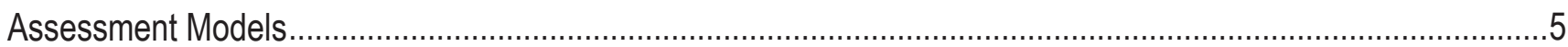

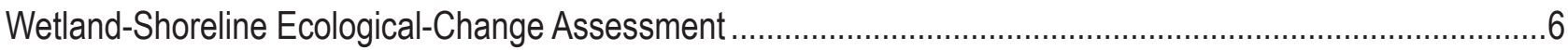

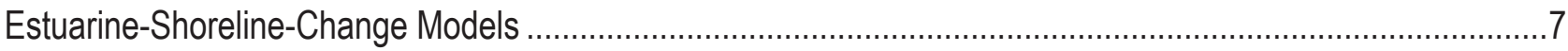

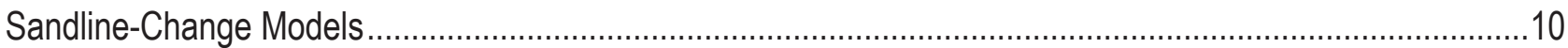

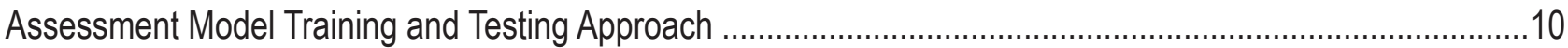

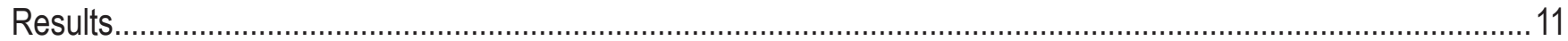

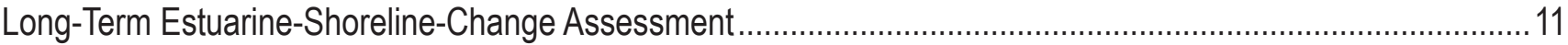

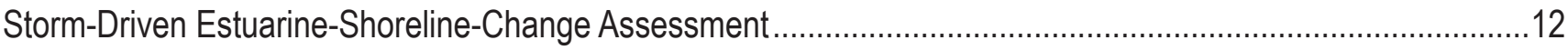

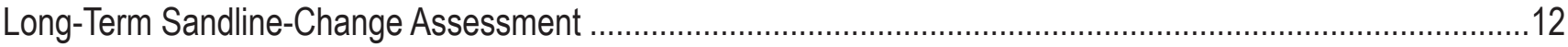

Storm-Induced Sandline-Change Assessment (Storm Driven) .................................................................. 15

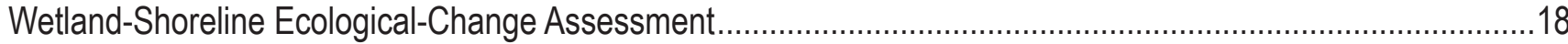

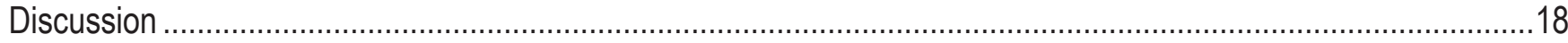

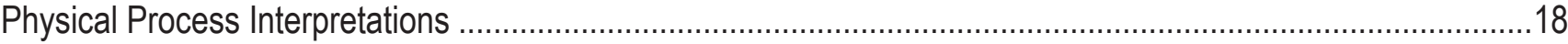

Alternate Approaches to Extending Remote-Sensing Observations Using Satellite Data ................................21

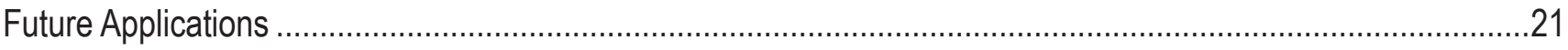

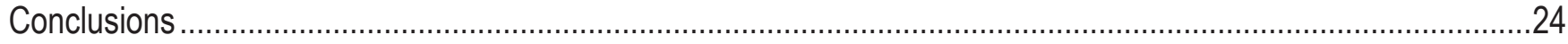

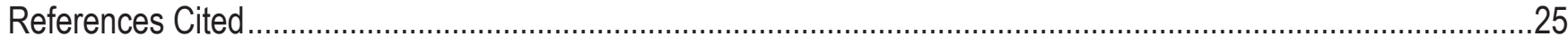

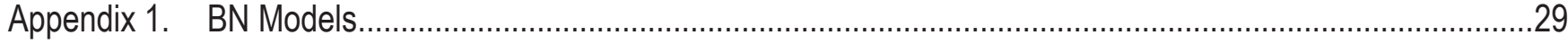

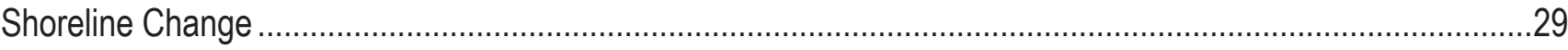

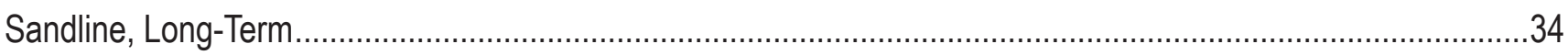

\section{Figures}

1. Example of barrier-island and wetland changes, Kegotank Bay, Virginia, showing overwash deposits burying marsh and tidal channels

2. Example of barrier-island and wetland data extracted from aerial imagery.............

3. Landsat 5 imagery classification based on radiometrically corrected image, unsupervised classification to identify water areas, and seven classes

4. Image showing marsh and overwash core locations at Assateague Island, Maryland and Virginia.............6

5. Example of overwash-deposit core from transect 4 showing a layer of peat intermixed with sand deposits 
6. Wetland-shoreline ecological-change assessment showing historical and modern classification of wetland vegetation or bare sand

7. Schematic diagram of model variables used to predict back-barrier-shoreline change.....

8. Schematic diagram of models used to predict long-term sandline change and Hurricane Sandy-induced sandline change

9. Maps showing the observed long-term and predicted long-term estuarine-shoreline change, and prediction certainty at Assateague Island, Maryland and Virginia

10. Maps showing the observed long-term and predicted long-term estuarine-shoreline change, and prediction certainty at Sandy Hook, New Jersey.

11. Maps showing the observed and predicted storm-driven estuarine-shoreline change, and prediction certainty at Assateague Island, Maryland and Virginia.

12. Maps showing the observed and predicted storm-driven estuarine-shoreline change, and prediction certainty at Sandy Hook, New Jersey.

13. Maps showing the observed and predicted long-term sandline change, and prediction certainty at Assateague-Island, Maryland and Virginia.

14. Maps showing the observed and predicted long-term sandline change, and prediction certainty at Sandy Hook, New Jersey.

15. Maps showing the observed and predicted storm-induced sandline change, and prediction certainty at Assateague Island, Maryland and Virginia.

16. Maps showing the observed Hurricane storm-induced sandline change, predicted Hurricane Sandyinduced sandline change, and prediction certainty at Sandy Hook, New Jersey

17. Maps showing assessment of back-barrier-shoreline type based on historical data and recent data at Assateague Island, Maryland and Virginia.

18. Maps showing assessment of back-barrier-shoreline type at Long Beach, New Jersey, based on historical data and recent data

19. Imagery, shorelines, and sandlines derived from aerial and satellite sources, and comparison of digitized sandlines and shorelines

20. Elements required to maintain and extend barrier-island estuarine-wetland physical-change analysis include updated observations of changes in features, associated data to tie these changes to physical processes, and updated models that address coastal management decisions

\section{Tables}

1. Combined data sources used to estimate changes attributed to long-term and Hurricane Sandy shoreline and sandline change.

2. Variables used in the shoreline-change and sandline-change models ...................................................

3. Long-term and storm-driven back-barrier-shoreline-change-prediction accuracy using weighted and unweighted skill with independent and hindcast models in the New Jersey and Assateague study areas .....12

4. Skill with independent and hindcast models for Skill metrics Sandline Change Bayesian Network output...15

5. Constant flux and sedimentation model results for the cores 20 


\section{Conversion Factors}

International System of Units to Inch/Pound

\begin{tabular}{|c|c|c|}
\hline Multiply & By & To obtain \\
\hline \multicolumn{3}{|c|}{ Length } \\
\hline centimeter $(\mathrm{cm})$ & 0.3937 & inch (in.) \\
\hline millimeter (mm) & 0.03937 & inch (in.) \\
\hline meter $(\mathrm{m})$ & 3.281 & foot $(\mathrm{ft})$ \\
\hline kilometer $(\mathrm{km})$ & 0.6214 & mile (mi) \\
\hline \multicolumn{3}{|c|}{ Area } \\
\hline square meter $\left(\mathrm{m}^{2}\right)$ & 0.0002471 & acre \\
\hline square kilometer $\left(\mathrm{km}^{2}\right)$ & 247.1 & acre \\
\hline square centimeter $\left(\mathrm{cm}^{2}\right)$ & 0.001076 & square foot $\left(\mathrm{ft}^{2}\right)$ \\
\hline \multicolumn{3}{|c|}{ Volume } \\
\hline cubic meter $\left(\mathrm{m}^{3}\right)$ & 264.2 & gallon (gal) \\
\hline liter $(\mathrm{L})$ & 61.02 & cubic inch $\left(\mathrm{in}^{3}\right)$ \\
\hline \multicolumn{3}{|c|}{ Flow rate } \\
\hline meter per year $(\mathrm{m} / \mathrm{yr})$ & 3.281 & foot per year ft/yr) \\
\hline millimeter per year $(\mathrm{mm} / \mathrm{yr})$ & 0.03937 & inch per year (in/yr) \\
\hline \multicolumn{3}{|c|}{ Mass } \\
\hline $\operatorname{gram}(\mathrm{g})$ & 0.03527 & ounce, avoirdupois (oz) \\
\hline \multicolumn{3}{|c|}{ Density } \\
\hline kilogram per cubic meter $\left(\mathrm{kg} / \mathrm{m}^{3}\right)$ & 0.06242 & pound per cubic foot $\left(\mathrm{lb} / \mathrm{ft}^{3}\right)$ \\
\hline gram per cubic centimeter $\left(\mathrm{g} / \mathrm{cm}^{3}\right)$ & 62.4220 & pound per cubic foot $\left(\mathrm{lb} / \mathrm{ft}^{3}\right)$ \\
\hline
\end{tabular}

\section{Datum}

Vertical coordinate information is referenced to the (insert datum name (and abbreviation) here, for example, North American Vertical Datum of 1988 (NAVD 88)).

Horizontal coordinate information is referenced to the (insert datum name (and abbreviation) here, for example, North American Datum of 1983 (NAD 83)).

Altitude, as used in this report, refers to distance above the vertical datum. 


\section{Abbreviations}

$\begin{array}{ll}\text { BN } & \text { Bayesian network } \\ \text { COAWST } & \text { coupled-ocean-atmosphere-wave-sediment transport } \\ \text { DOQQ } & \text { digital orthophoto quarter quadrangle } \\ \text { DSAS } & \text { Digital Shoreline Analysis System } \\ \text { GPR } & \text { ground-penetrating radar } \\ \text { HS } & \text { storm driven } \\ \text { LLR } & \text { likelihood ratio } \\ \text { LSR } & \text { linear sedimentation rate } \\ \text { LT } & \text { long term } \\ \text { M } & \text { number of predicted outcomes } \\ \text { NOAA } & \text { National Oceanic and Atmospheric Administration } \\ \text { USGS } & \text { U.S. Geological Survey }\end{array}$




\title{
Barrier-Island and Estuarine-Wetland Physical-Change Assessment after Hurricane Sandy
}

\author{
By Nathaniel G. Plant, Kathryn E.L. Smith, Davina L. Passeri, Christopher G. Smith, and Julie C. Bernier
}

\section{Introduction}

The Nation's eastern coast is fringed by beaches, dunes, barrier islands, wetlands, and bluffs. These natural coastal barriers provide critical benefits and services, and can mitigate the impact of storms, erosion, and sea-level rise on our coastal communities. Waves and storm surge resulting from Hurricane Sandy, which made landfall along the New Jersey coast on October 29, 2012, impacted the U.S. coastline from North Carolina to Massachusetts, including Assateague Island, Maryland and Virginia, and the Delmarva coastal system. The storm impacts included changes in topography, coastal morphology, geology, hydrology, environmental quality, and ecosystems (Buxton and others, 2013).

In the immediate aftermath of the storm, light detection and ranging (lidar) surveys from North Carolina to New York documented storm impacts to coastal barriers, providing a baseline to assess vulnerability of the reconfigured coast. The focus of much of the existing coastal change assessment is along the ocean-facing coastline (Sopkin and others, 2014); however, much of the coastline affected by Hurricane Sandy includes the estuarine-facing coastlines of barrier-island systems. Specifically, the wetland and back-barrier shorelines experienced substantial change as a result of wave action and storm surge that occurred during Hurricane Sandy (fig. 1; see also USGS photograph, http://coastal.er.usgs.gov/hurricanes/sandy/photo-comparisons/virginia.php). Assessing physical shoreline and wetland change (land loss as well as land gains) can help to determine the resiliency of wetland systems that protect adjacent habitat, shorelines, and communities.

To address storm impacts to wetlands, a vulnerability assessment should describe both longterm (for example, several decades) and short-term (for example, Sandy's landfall) extent and character of the interior wetlands and the back-barrier-shoreline changes. The objective of this report is to describe several new wetland vulnerability assessments based on the detailed physical changes estimated from observations. The scope includes understanding changes caused by both short- and long-term processes using both remotely sensed and in situ observations to characterize changes to the wetland in terms of accretion/expansion and erosion/contraction. Accretion may be due to net vertical and (or) horizontal deposition, including estuarine-shoreline change due to overwash. Wetland erosion may be due to elevated waves and water levels in the estuary itself. We included additional information based on wave runup and storm-surge elevations based on models (Aretxabaleta and others, 2014; Birchler and others, 2014; Zambon and others, 2014; Ganju and others, 2016; U.S. Geological Survey, 2016a) and elevation data (Stockdon and others, 2013; Overbeck and others, 2017). We then developed a predictive assessment for wetland vulnerability that describes the likelihood of changes of the estuarine shoreline and the landward extent of sand overwash driven by processes occurring on the ocean-facing shoreline. This assessment is intended to be linked to the beach and dune vulnerability assessments that have been developed previously (Doran and others, 2012; Stockdon and others, 2012; Birchler and others, 2014). 


\section{Methods}

Historical and modern maps, aerial photographs, satellite imagery, and lidar elevation data were included in this analysis to document physical changes associated with Hurricane Sandy and to provide a long-term context for this storm event. Surficial sediments, sediment cores, and geophysical data were collected and analyzed to characterize Hurricane Sandy sediment deposits and historical deposits along the barrier island as well as the barrier and mainland estuarine shorelines. These ground-truth data serve to document the depositional amounts attributed to Hurricane Sandy and can be used to interpret the results of the remotely-sensed wetland change analysis; they also provide historical deposition to put Hurricane Sandy in a broader context. The detailed analysis of the sediment data provides an accurate understanding of site-specific sensitivity of deposition associated with cross-barrier sediment transport and transport associated with estuarine processes.
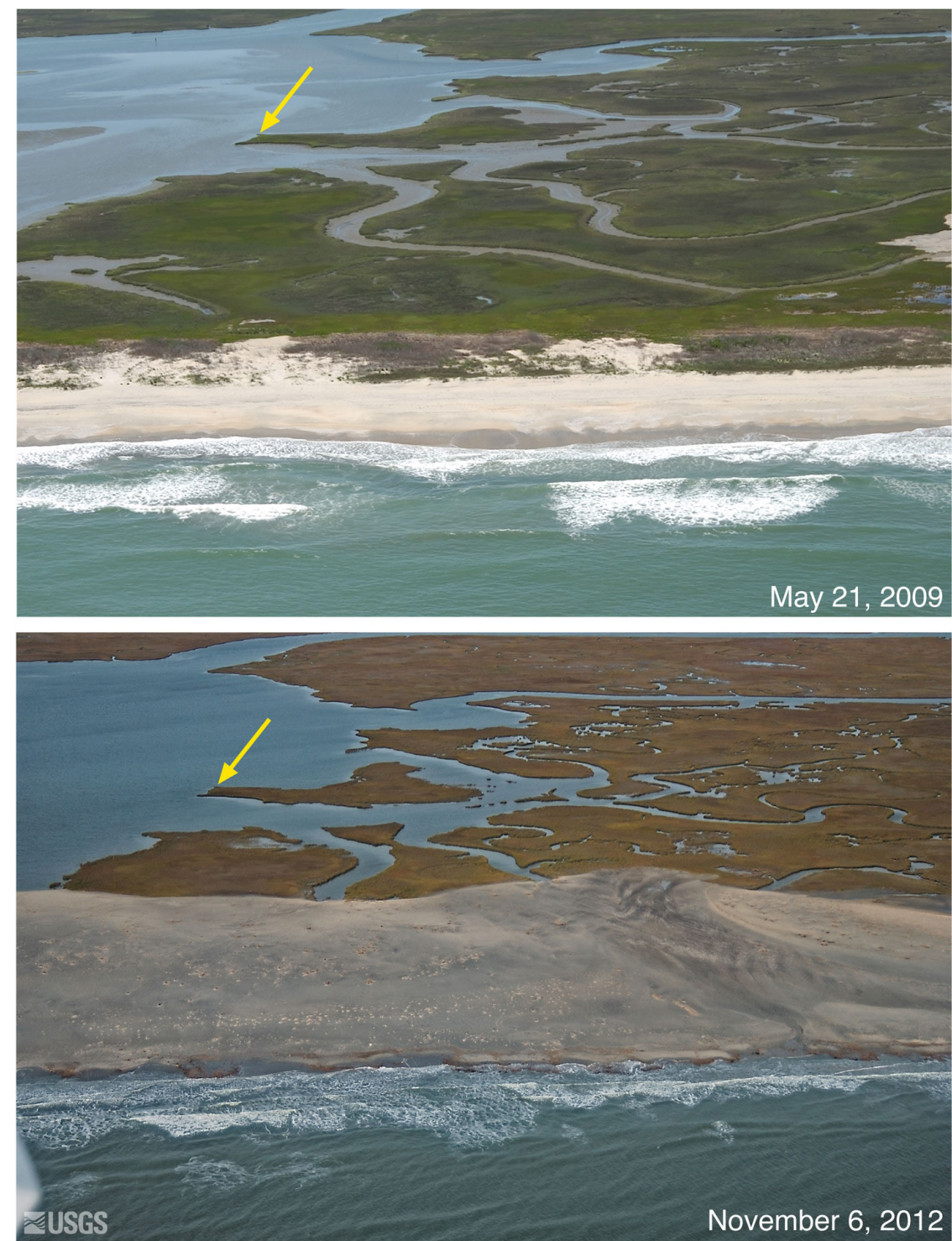

Figure 1. Example of barrier-island and wetland changes, Kegotank Bay, Virginia, showing overwash deposits burying marsh and tidal channels. (Yellow arrow marks a reference feature that is visible in each image.) 
The approach to developing an assessment of estuarine-shoreline and wetland physical changes consisted of the following three components:

- identifying and measuring estuarine-shoreline changes resulting from Hurricane Sandy along Virginia, Maryland, and New Jersey coastlines using remotely sensed data;

- sampling and analyzing sediment cores to understand long-term geologic processes and provide ground-truth measurements for the remote-sensing analysis; and

- assessing the likelihood of wetland change resulting from future storm events or long-term processes and linking to the existing beach and dune vulnerability assessment.

\section{Remotely Sensed Data}

The approach used for measuring changes from remotely sensed data (fig. 2) has been published previously (Bernier and others, 2015; Guy, 2015b; c). To summarize, several coastal features were extracted from aerial photography spanning the period from the late 1980s to just after Hurricane Sandy's landfall on October 29, 2012. The variables used to quantify coastal change included the ocean-facing shoreline position (digitized at the visually identified water line), the estuarine (back-barrier) shoreline,

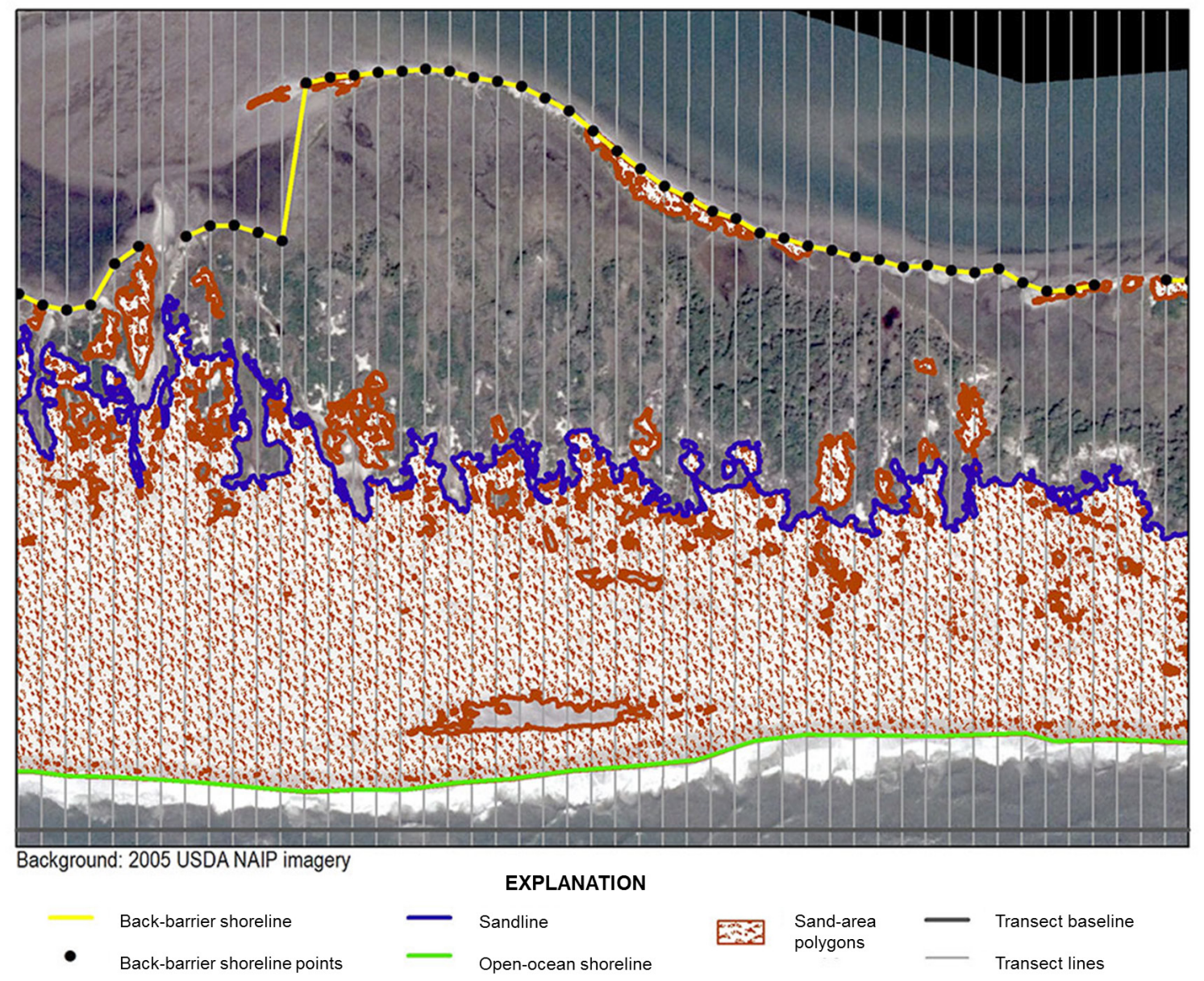

Figure 2. Example of barrier-island and wetland data extracted from aerial imagery. 
and areas of unvegetated sand. The landward limit of these unvegetated sand areas denotes a sandline that identifies the landward extent of overwash immediately after storms and it identifies the seaward extent of vegetation, as plant recolonization takes place long after overwash occurs.

The specific remote-sensing data required by this assessment were augmented by additional data that had been derived previously (Himmelstoss and others, 2010; National Oceanic and Atmospheric Administration, 2016; Swiderski and others, 2016) and these data were combined to estimate barrier and wetland changes at two timescales: a long-term linear regression to determine change rates over the past decades and a quantification of the net change attributed to Hurricane Sandy. The combined data sources utilized for these analyses are described in table 1.

Table 1. Combined data sources used to estimate changes attributed to long-term and Hurricane Sandy shoreline and sandline change.

\begin{tabular}{|c|c|c|c|}
\hline Years of data for New Jersey & Years of data for Assateague Island & Source & Publisher \\
\hline $\begin{array}{l}1880,1881,1883,1899,1926,1927, \\
1932,1943,1950,1970,1974 \text {, and } \\
1981\end{array}$ & $\begin{array}{l}1849,1850,1915,1933,1942,1959 \\
1961 \text { and } 1962\end{array}$ & T-sheet ${ }^{*}$ & $\mathrm{NOAA}^{1}$ \\
\hline 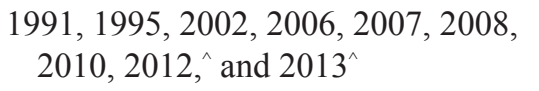 & $\begin{array}{l}1989,1994,2004,2005,2006,2007, \\
2008,2009,2011, \wedge 2012^{\wedge} \text { and } 2013^{\wedge}\end{array}$ & $\mathrm{DOQQ}^{2}$ & $\mathrm{USGS}^{3}$ \\
\hline \multicolumn{4}{|c|}{$\begin{array}{l}\text { *Data used to obtain oceanfront and back-barrier shorelines only (no sandlines). } \\
\text { 'Data used for pre- and post-Hurricane Sandy change estimates. } \\
\text { 'National Oceanic and Atmospheric Administration; see https://shoreline.noaa.gov/data/datasheets/t-sheets.html. } \\
{ }^{2} \text { Digital orthophoto quarter quadrangle image. } \\
\text { 'U.S. Geological Survey; see https://doi.org/10.3133/ds960; https://doi.org/10.3133/ds928. }\end{array}$} \\
\hline
\end{tabular}

Change rates of the shorelines (ocean facing and estuarine) and sandlines were estimated along linear transects perpendicular to the shore, with transects separated by 50-meter spacing in the alongshore direction. The Digital Shoreline Analysis System (DSAS; ver. 4.3.4730 for ArcGIS 10) (Thieler and others, 2008) was used to estimate linear regression rates for the long-term analysis and net shoreline movement was used to compute shoreline change from the period immediately before and immediately after Hurricane Sandy's landfall. These estimates of shoreline change are available as U.S. Geological Survey data releases (Terrano and Smith, 2015). Sandline movement was estimated similarly, with net movement between pre-sandline and post-sandline position as the metric of change.Although we will rely on the high-resolution aerial imagery for the analysis presented here, we were interested in developing an observation and analysis approach that could be applied broadly along the Nation's coastlines and updated with new data rapidly and automatically. Previous work assessed the utility of Landsat imagery (fig. 3) for extracting shorelines and sandlines (Bernier and others, 2015). We will discuss the relevance of additional data sources to broader scale implementation (that is, national-scale as opposed to the regional demonstrations presented here) of the approaches presented in this report.

\section{Sedimentological Data and Analysis}

Sedimentological data (figs. 4 and 5) have been collected previously at Assateague Island, Maryland and Virginia (hereinafter, we refer to this region simply as Assateague), in order to sample depositional characteristics in the wetlands (Smith and others, 2015) and the deposition associated with overwash from the ocean into the wetlands (Bernier and others, 2016; Zaremba and others, 2016a). These 


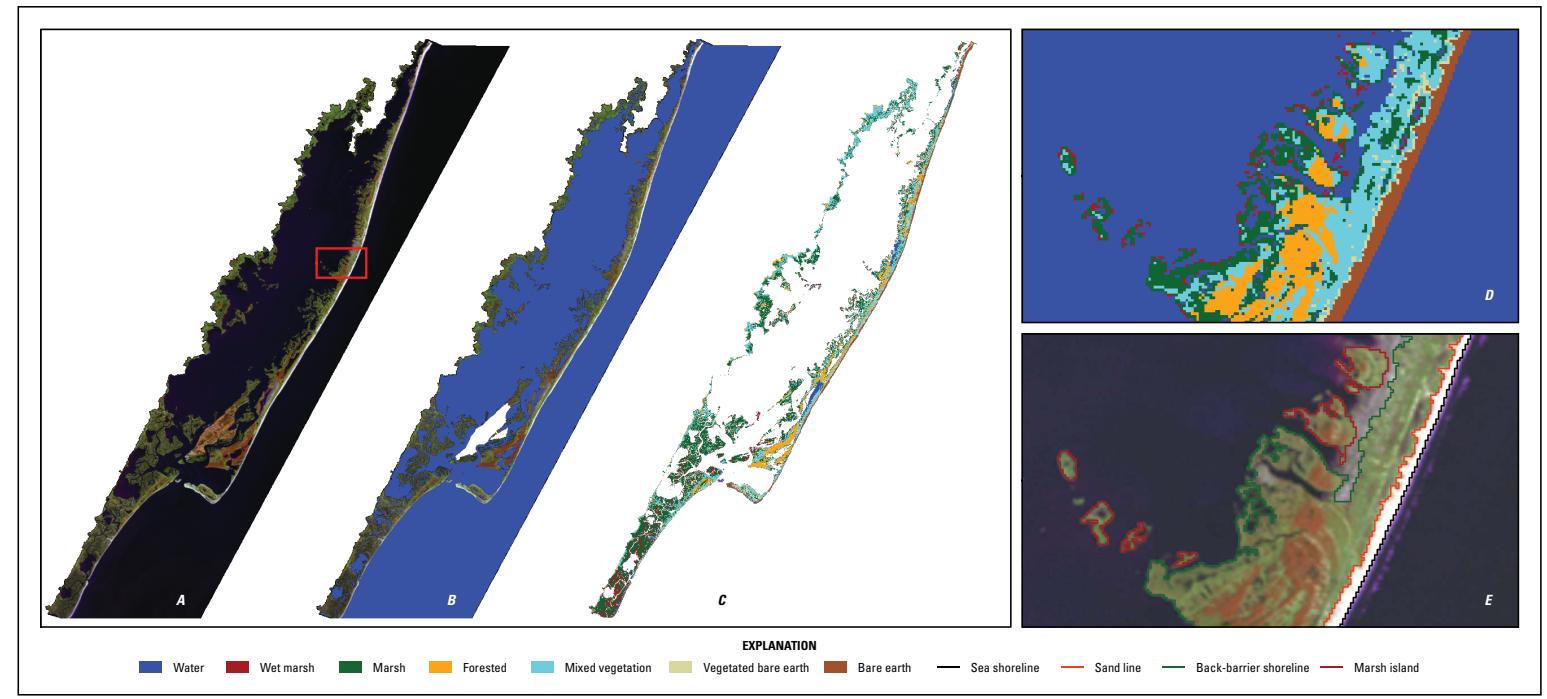

Figure 3. Landsat 5 imagery classification based on $(A)$ radiometrically corrected image, $(B)$ unsupervised classification to identify water areas, and $(C)$ seven classes (water, wet marsh, marsh, forested, mixed vegetation, vegetated bare earth, and bare earth). The enlargement shows $(D)$ sample classifications and $(E)$ line features.

ground-truth samples add both a broader historical context and constrain depositional processes that can only be inferred, but not directly inspected, from the image-based observations used to assess barrier and wetland physical changes. Additional data collection has occurred at Forsythe National Wildlife Refuge, New Jersey (Bishop and others, 2016b; Bishop and others, 2016a), and Fire Island, New York (La Selle and others, 2017), where sediment cores were sampled and analyzed to interpret overwash depositional processes. The sedimentological analysis of the cores includes estimates of grain-size distributions and texture, water content, bulk density, porosity, organic content, and radiometric analysis of lead-210 (Pb-210). The sedimentological analysis results in a description of the depositional textures and rates which are used to infer depositional processes responsible for observed estuarine-shoreline and sandline changes. Coincident with the overwash sediment sampling, ground-penetrating radar (GPR) surveys were conducted to resolve the stratigraphy that connects the discrete sample locations where sediment cores were recovered (Zaremba and others, 2016a; Zaremba and others, 2016b). These data can be related to the geologic structure produced by barrier-island evolution, and can be related to actual elevation changes, such as those measured using lidar methods (Stockdon and others, 2013; Sopkin, 2014; Wright and others, 2014).

\section{Assessment Models}

The variables that are used to assess long-term changes (that is, occurring over decades to centuries) and short-term changes (that is, due to Hurricane Sandy) to the barrier wetlands are (1) the estuarine shoreline, (2) the sandline (which describes the interaction between ocean processes, via overwash, and the interior or estuary side of the island), as well as (3) the actual degree of vegetation at the estuarine-shoreline edge. The regression and event-based analysis of the remote-sensing-derived data characterize our best estimates of actual changes, but they do not capture the sensitivities of those changes to geomorphic, vegetation-mediated, or oceanographic drivers of sediment transport and deposition. We developed several predictive models to assess our ability to relate estuarine-shoreline and sandline changes to a broader set of variables that are intended to capture the processes that actually cause wetland changes. 


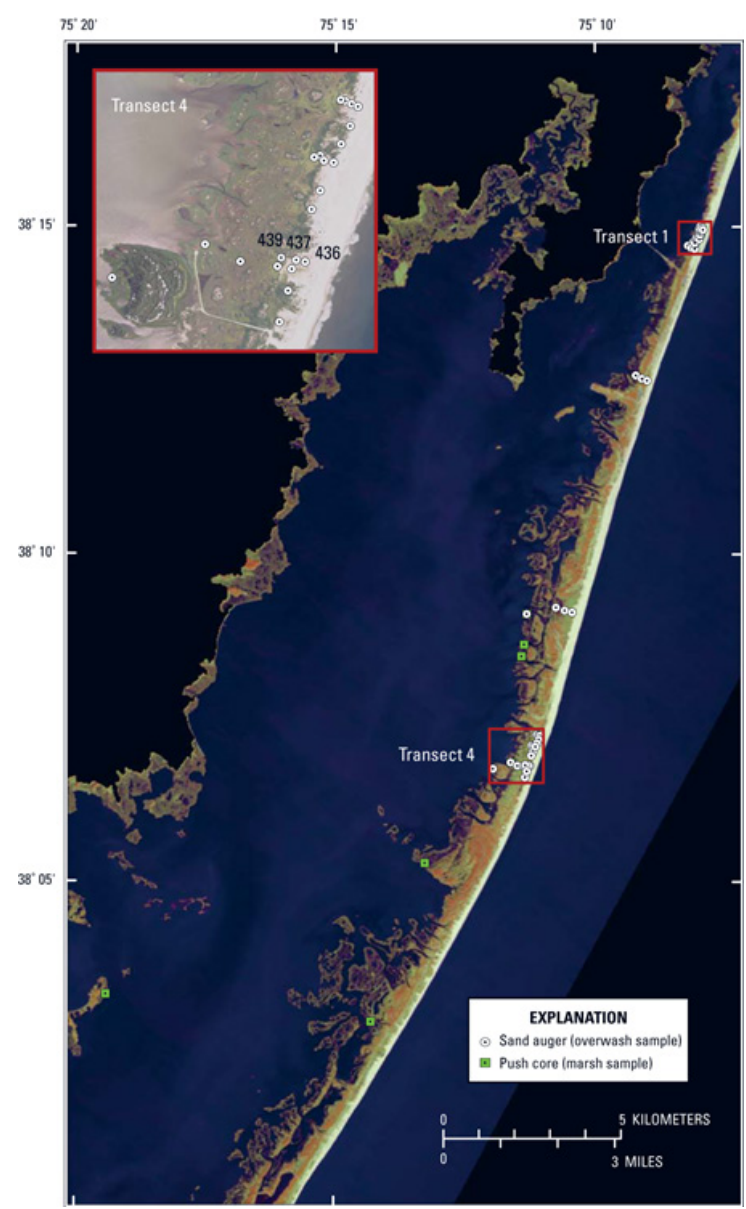

Figure 4. Image showing marsh and overwash core locations at Assateague Island, Maryland and Virginia.

The first two assessments are implemented numerically using Bayesian networks (BN). Bayesian networks (appendix 1) have been used by others to predict shoreline changes due to sea-level rise (Gutierrez and others, 2011), to predict shoreline and dune erosion due to extreme storms (Plant and Stockdon, 2012), and to relate diverse geomorphic features occurring on barrier islands to each other (Gutierrez and others, 2015). An advantage of the $\mathrm{BN}$ approach is that it formalizes the expected correlations between input and output variables of a coastal-change process, even if an explicit numerical model for these processes does not exist, and it can capture the expected uncertainty due to variability in the accuracy of the input and output data. The third assessment characterizes the observed, long-term changes in the conversion of vegetated and unvegetated wetland shoreline in order to resolve the ecological changes that are associated with the physical changes that are evaluated by the first two assessments.

\section{Wetland-Shoreline Ecological-Change Assessment}

Smith and others (2015) define the following two different types of evolutionary pathways for back-barrier marshes based on seven cores from marshes around Assateague Island: (1) young, emergent marshes adjacent to low-relief barrier islands and (2) established marsh platforms along more protected regions of the barrier island (fig. 6). If existing backshore land cover is not persistently bare sand, as is the case for areas that perpetually overwash, then they may be old wetlands that have remained so over the long term (100+ years) and, therefore, are not dominated by recent overwash (Bernier and others, 2016; Zaremba and others, 2016a). Other possible explanations are that the wetland can be newly 

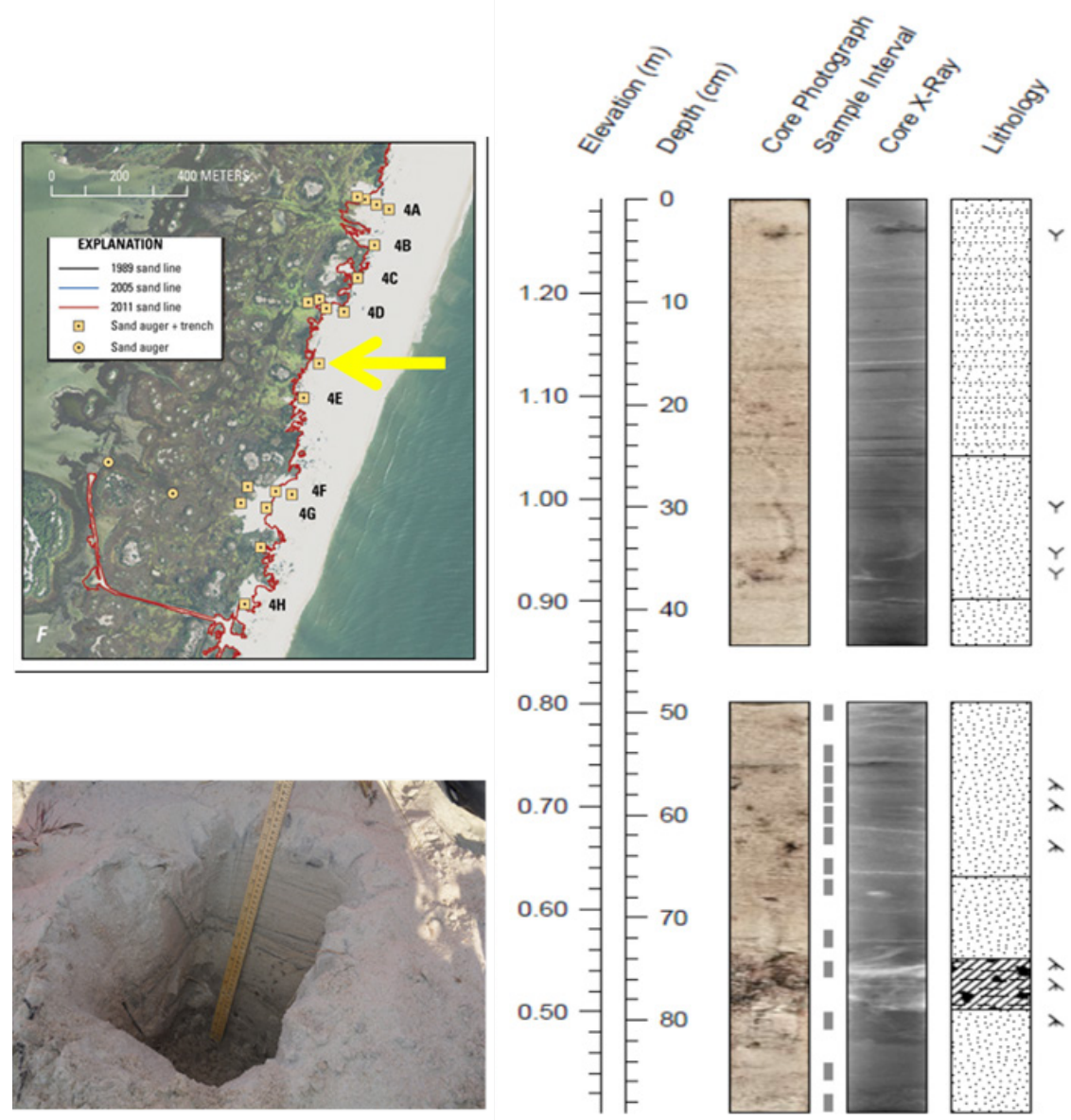

Figure 5. Example of overwash-deposit core from transect 4 (core id 14CTB-427W) showing a layer of peat intermixed with sand deposits.

colonized overwash or flood-tide-shoal deposits, or they can be wetlands that have been converted to sandy environments through burial from overwash. These classifications of the ecological transition assessments are valuable additional information that can be used to interpret the physical changes in the positions of shorelines and sandlines.

\section{Estuarine-Shoreline-Change Models}

Storm-driven (HS) and long-term (LT) estuarine-shoreline changes are influenced by oceanic, estuarine, and geomorphic variables. To capture these influences statistically, a BN model was constructed that used input variables that reflected the process of barrier-island overwash and barrier-island migration (also called barrier-island rollover). These variables (fig. 7; table 2) include barrier-island height, width, and ocean-front wave height, which influence the likelihood of overwash occurring and modulate the impacts of overwash at the estuarine shoreline. Estuary width, depth, and estuarine waveheight influence estuarine-shoreline erosion and accretion. The long-term ocean-facing shoreline change is driven by storms and sea-level rise (Gutierrez and others, 2011) and is a driver of both long-term barrier-island migratory processes. The shoreline change on the estuarine side of the island is one of the predicted variables in the model (LT backshore change, fig. 7). Likewise, ocean-front storm-driven shoreline change should represent short-term, storm-influenced drivers of the short-term backshore change (HS backshore change, fig. 7). 

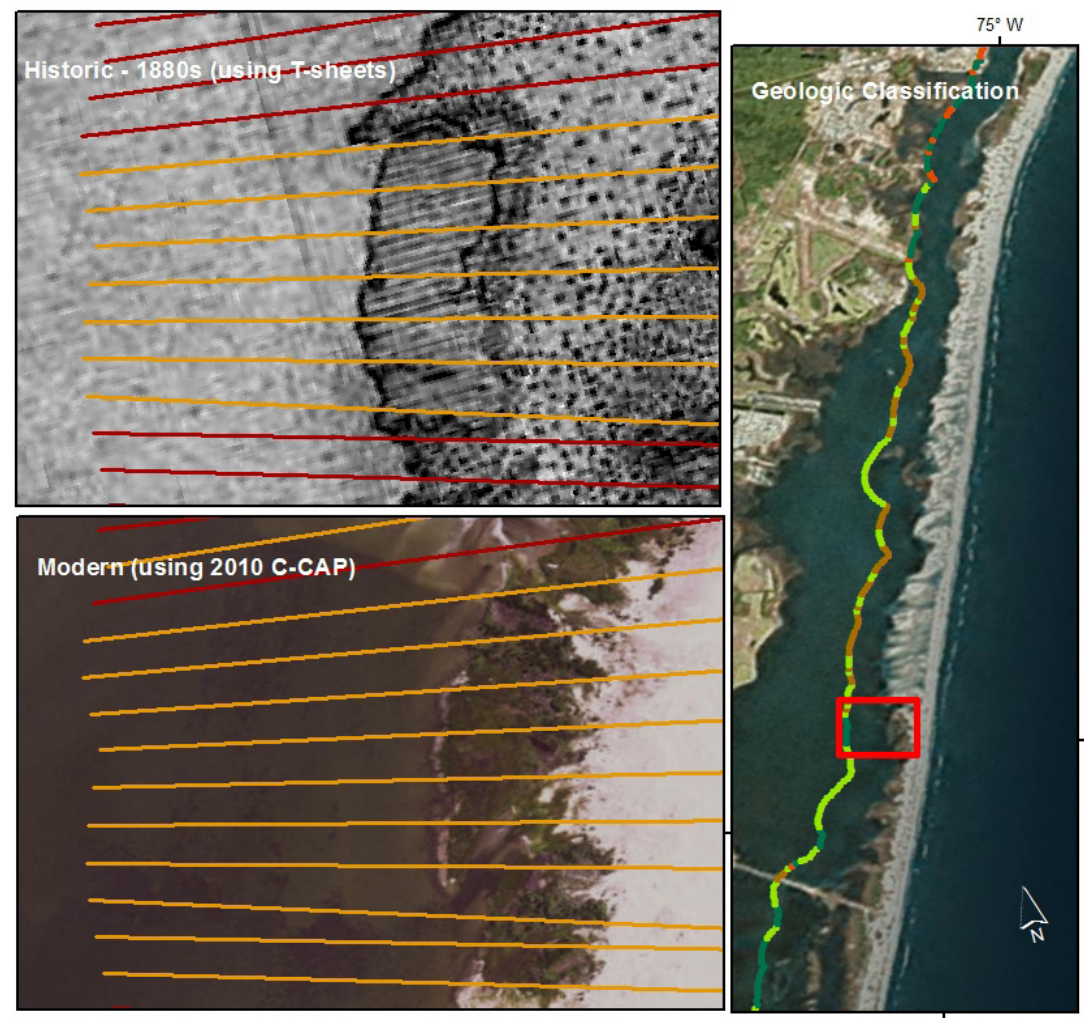

EXPLANATION

Historic and modern

shoreline classification

-..... No data

L Land

Wetland

Geologic classification

- No data

- Land

- Buried wetland

- New wetland

- Old wetland

KLOMETERS

$\begin{array}{llll}0.5 & 1 & 2\end{array}$

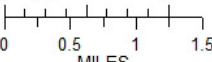

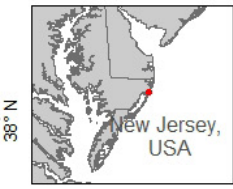

Base map Source: Esri

DigitalGlobe, GeoEye,

Geographics, CNE

SS, USDA USGS/Arbus

Getmapping. Aerogrid,

IGN, IGP, swisstopo, and

the GIS User Community

Figure 6. Wetland-shoreline ecological-change assessment showing historical (top left) and modern (bottom left) classification of wetland vegetation or bare sand. The assessment (right) describes the state changes of ecological classifications.

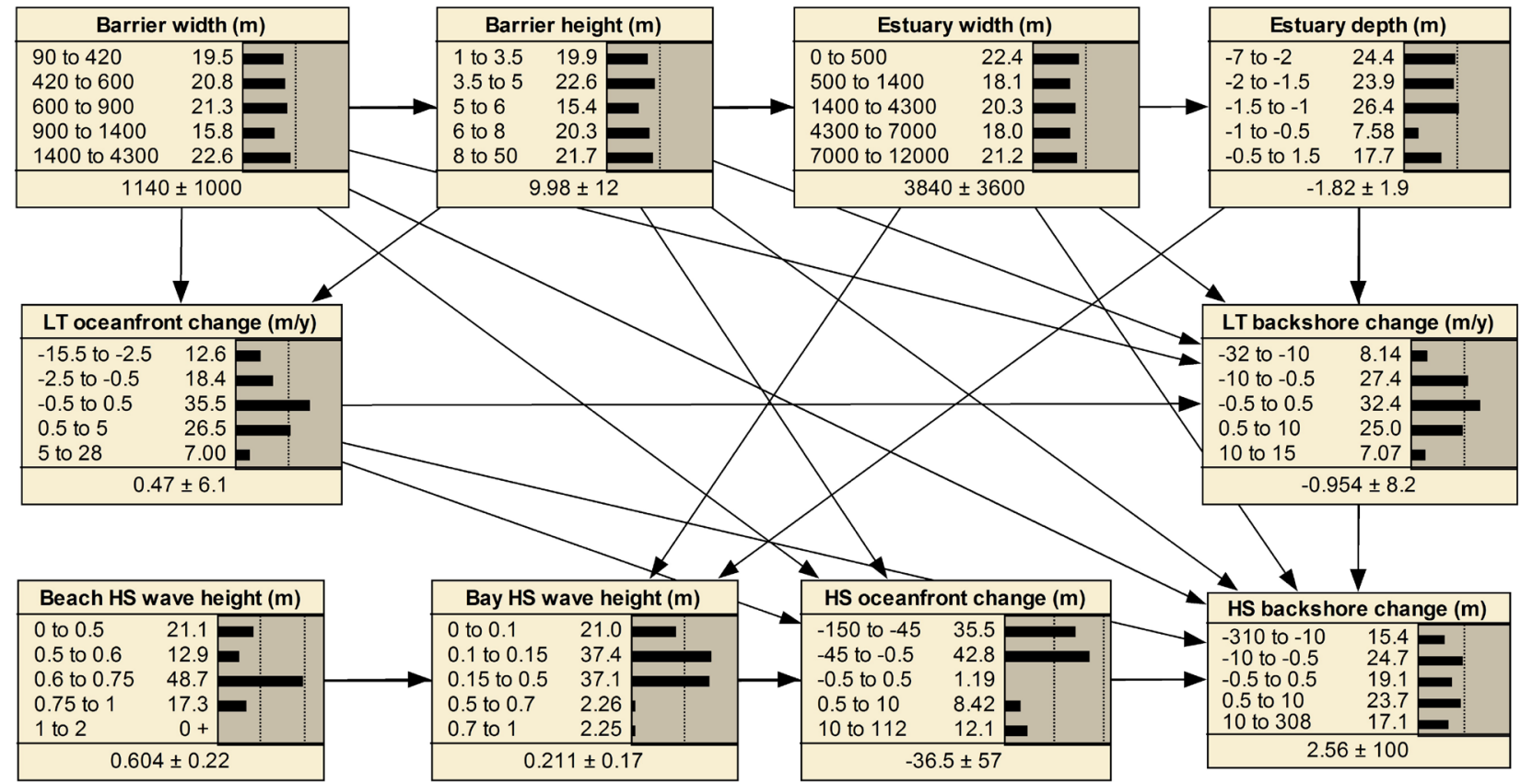

Figure 7. Schematic diagram of model variables used to predict back-barrier-shoreline change $(\mathrm{m}, \mathrm{meter} ; \mathrm{m} / \mathrm{y}$, meters per year). 
Table 2. Variables used in the shoreline-change and sandline-change models.

[m, meters; $\mathrm{m} / \mathrm{y}$, meters per year; HS, storm driven; LT, long term]

\begin{tabular}{|c|c|c|}
\hline Variable & Description & Model \\
\hline Barrier width & $\begin{array}{l}\text { Distance }(\mathrm{m}) \text { between the back-barrier and the oceanic shoreline calcu- } \\
\text { lated using areal imagery (Guy, 2015b; Guy, 2015c) }\end{array}$ & $\begin{array}{l}\text { Shoreline } \\
\text { Sandline (LT\&HS) }\end{array}$ \\
\hline Barrier height & $\begin{array}{l}\text { Maximum height }(\mathrm{m}) \text { of the barrier island, extracted from lidar data that } \\
\text { were acquired in } 2010 \text { and } 2012 \text { (National Atmospheric and Oceanic } \\
\text { Administration [NOAA], 2010; Bonisteel-Cormier and others, 2011; } \\
\text { U.S. Geological Survey, 2016b) }\end{array}$ & $\begin{array}{l}\text { Shoreline } \\
\text { Sandline (LT\&HS) }\end{array}$ \\
\hline Estuary width & $\begin{array}{l}\text { Width }(\mathrm{m}) \text { of the estuary from the back-barrier shoreline to the closest land } \\
\text { (mainland or other island) shoreline (Terrano and Smith, 2015) }\end{array}$ & Shoreline \\
\hline Estuary depth & $\begin{array}{l}\text { Maximum depth of the estuary }(\mathrm{m}) \text {, obtained from the Ocean City digital } \\
\text { elevation model published by NOAA }\end{array}$ & Shoreline \\
\hline $\begin{array}{l}\text { LT ocean-front change } \\
\text { or }\end{array}$ & $\begin{array}{l}\text { Long-term ocean-facing shoreline change rates (m/y), calculated from } \\
\text { historical shorelines spanning 1845-2000 (Terrano and Smith, 2015) }\end{array}$ & Shoreline \\
\hline $\begin{array}{l}\text { LT ocean shoreline } \\
\text { change }\end{array}$ & & Sandline (LT \& HS) \\
\hline LT backshore change & $\begin{array}{l}\text { Long-term backshore-shoreline change rates (m/y), calculated from his- } \\
\text { torical shorelines spanning } 1849 \text { to } 2013 \text { (Terrano and Smith, 2015) }\end{array}$ & Shoreline \\
\hline $\begin{array}{l}\text { Beach HS wave height } \\
\text { or } \\
\text { ocean-wave height }\end{array}$ & $\begin{array}{l}\text { Hurricane Sandy ocean wave height }(\mathrm{m}) \text { obtained from U.S. Geological } \\
\text { Survey's reanalysis model results (U.S. Geological Survey, 2016a) }\end{array}$ & $\begin{array}{l}\text { Shoreline } \\
\text { Sandline (LT) }\end{array}$ \\
\hline Bay HS wave height & $\begin{array}{l}\text { Maximum height of Hurricane Sandy estuary wave height }(\mathrm{m}) \text { for the } \\
\text { bay side of the island from reanalysis model (U.S. Geological Survey, } \\
\text { 2016a) }\end{array}$ & Shoreline \\
\hline HS oceanfront change & $\begin{array}{l}\text { Net shoreline movement }(\mathrm{m}) \text { calculated by the Digital Shoreline Analysis } \\
\text { System (DSAS) for the pre- and post-Hurricane Sandy foreshore rate of } \\
\text { change analysis (Terrano and Smith, 2015) }\end{array}$ & Shoreline \\
\hline HS backshore change & $\begin{array}{l}\text { Net shoreline movement }(\mathrm{m}) \text { calculated by DSAS for the pre- and post- } \\
\text { Hurricane Sandy backshore rate of change analysis (Terrano and Smith, } \\
\text { 2015) }\end{array}$ & Shoreline \\
\hline $\begin{array}{l}\text { Hurricane Sandy surge } \\
\text { elevations }\end{array}$ & $\begin{array}{l}\text { Hindcast hydrodynamic simulations of water level (m) using a model with } \\
\text { separate model domains for Chincoteague Bay, Maryland and Virginia } \\
\text { (U.S. Geological Survey, 2016c), and Barnegat Bay, New Jersey (U.S. } \\
\text { Geological Survey, 2016d). The maximum surge elevation was inter- } \\
\text { polated to the 20-m isobath along the coastline and projected onto the } \\
\text { shoreline at 10-m-spaced transects. }\end{array}$ & Sandline (HS) \\
\hline $\begin{array}{l}\text { Hurricane Sandy runup } \\
\text { elevations }\end{array}$ & $\begin{array}{l}\text { Maximum runup (m) expected for Hurricane Sandy, calculated using the } \\
\text { Stockdon and others, } 2007 \text { parameterization, using wave heights from } \\
\text { the coupled ocean-atmosphere-wave-sediment transport (COAWST) } \\
\text { model provided (U.S. Geological Survey, 2016b, a, d, c) }\end{array}$ & Sandline (HS) \\
\hline $\begin{array}{l}\text { Long-term sandline } \\
\text { change }(\mathrm{m} / \mathrm{y})\end{array}$ & Determined from the methods described in Terrano and Smith, 2015 & Sandline (LT\&HS) \\
\hline $\begin{array}{l}\text { Hurricane Sandy sand- } \\
\text { line change }(\mathrm{m})\end{array}$ & Determined from the methods described in Terrano and Smith, 2015 & Sandline (LT\&HS) \\
\hline
\end{tabular}




\section{Sandline-Change Models}

Two BN models were constructed to predict long-term (estimated over decadal time periods) and Hurricane Sandy-induced sandline change along the Assateague and New Jersey coasts. Geomorphic and hydrodynamic variables derived from the remote-sensing analysis and numerical model output were extracted at 50-m-spaced transects (Terrano and Smith, 2015). The eight variables used in the BN models are divided into three categories: driving forces (that is, maximum ocean wave height, surge height, and runup height during Hurricane Sandy, and long-term ocean shoreline change), geological boundary conditions (that is, barrier-island height and barrier-island width), and response variables (that is, Hurricane Sandy-induced sandline change and long-term sandline change). Correlations between variables are represented with interconnected nodes that are resolved into discrete bins representing a range of scenarios spanned by the input data (fig. 8). The nodes are connected based on the understanding of how each variable relates to one another. The conditional probabilities that relate each variable are determined from the existing datasets (Terrano and Smith, 2015). Negative values of sandline change indicate the landward extent of overwash deposits (that is, the sandline), whereas positive values indicate the seaward extent of the sandline resulting from processes such as storm-surge ebb flows or vegetation growth.

\section{Assessment Model Training and Testing Approach}

Each model is tested on its ability to predict changes in long-term and event-driven (that is, Hurricane Sandy-induced) backshore and sandline change based on learned correlations from the input variables across the domain. Using the input hydrodynamic and geomorphic data, the BN is constrained to produce a prediction of an updated conditional probability of backshore or sandline change at each location. The BN predictions are produced at the same spatial scale as the input variables. At locations where some or all of the data are missing (for example, due to differences in the spatial resolution of the datasets), predictions can still be made because missing data are taken into account with prediction
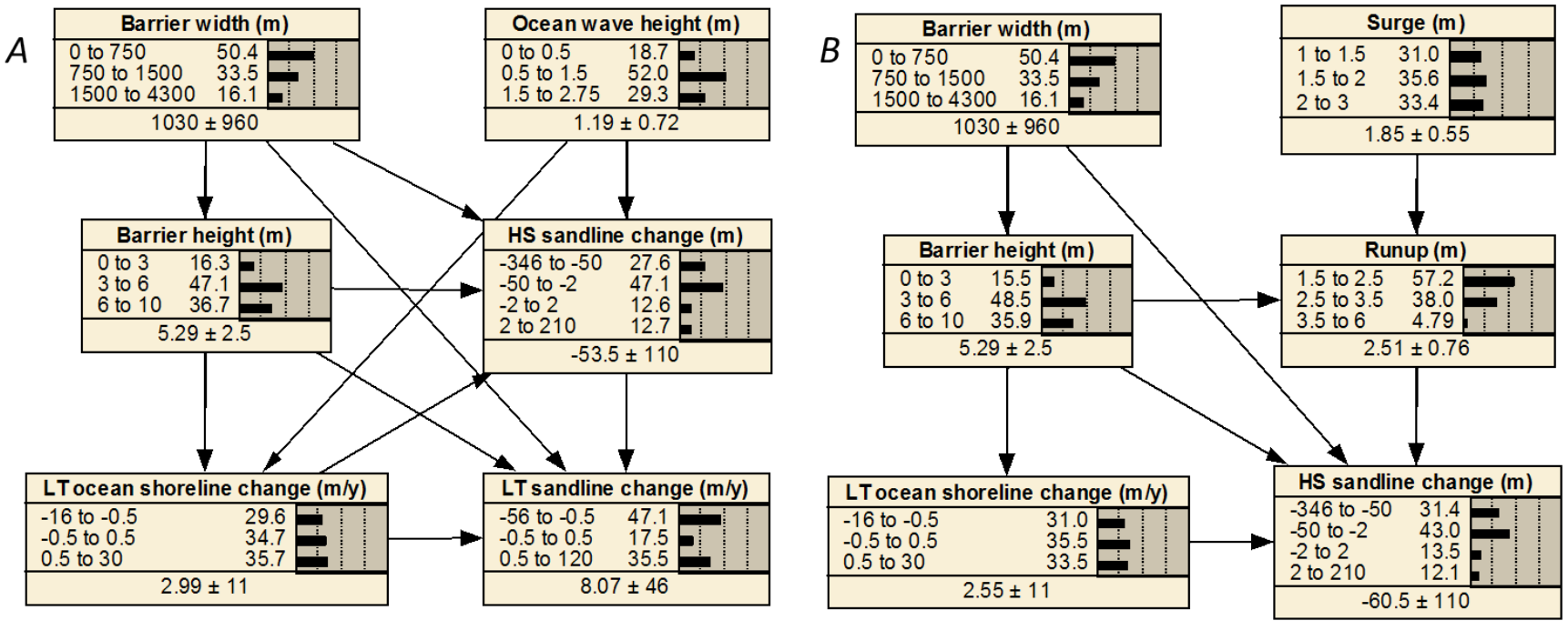

Figure 8. Schematic diagram of models used to predict $A$, long-term (LT) sandline change, and $B$, Hurricane Sandy-induced sandline change. In $A$, the ocean wave height, Hurricane Sandy-induced sandline change, and LT ocean-shoreline change are considered to be driving forces; barrier-island width and barrier-island height are considered to be boundary conditions, and the long-term sandline change is the response variable. In $B$, Hurricane Sandy surge elevation, runup height, and LT ocean-shoreline change are considered to be driving forces; barrier-island width and barrier-island height are considered to be boundary conditions; and the Hurricane Sandy sandline change is the response variable. 
uncertainty. For example, with no specific inputs, the BN prediction returns the prior distribution of the output variable, which reflects the spatial variability of that variable over the entire study area.

To evaluate the ability of the BN to reproduce the observations used to train the model, three statistical metrics were computed: the skill, log likelihood ratio (LLR), and success rate. The skill score calculates the fraction of the observed variance that is explained by the model predictions, averaged over all possible outcomes, and can be computed using just the predicted value or using a weight that depends on the confidence of the prediction (Plant and others, 2016). The LLR ratio measures the performance of the predictions relative to an alternative model consisting of the prior probabilities. If the likelihood of the updated prediction increases over the prior, the log likelihood ratio is positive, meaning that the update is either more accurate or more certain (or both). If the updated prediction is worse than the prior, the log likelihood ratio is negative; this may occur if the predicted outcome has a high probability but differs from the observed outcome. The definitions of skill and likelihood ratios are given in equations 4 and 5 in Plant and others (2016). The success rate was calculated as the percentage of cases where the observed backshore or sandline change fell within the discrete bin with the highest predicted probability (that is, the most likely change prediction). The percentage of cases where the observation fell within an adjacent bin to the most likely prediction was also calculated. The evaluations were performed to test the calibration accuracy, where the tests were performed on the same data that were used to train the model. And the tests were performed on validation datasets, where data used for testing were different from the calibration data. This was done by splitting data from different geographic locations, such that training was conducted on data from New Jersey, and testing was conducted on data from New Jersey (calibration testing) and Virginia and Maryland (validation testing).

\section{Results}

Here, we present the results of the BN model predictions and the ecological assessment. The trained BN models can be used to make probabilistic predictions of long-term or short-term changes. BN models predict the likelihood of a number of different outcomes based on constraints provided by the input variables at each location. Then, the most likely outcome (result with highest likelihood) or expected outcome (mean-value based on results) can be used to represent future long-term response of the coastline or response to a Hurricane Sandy-like storm. The degree of uncertainty in the assessment can be measured by the probability associated with the most likely outcome, where 100 percent indicates the highest assessment confidence and 100/M percent (where $\mathrm{M}$ is the number of predicted outcomes) indicates an extremely uncertain assessment: $\mathrm{M}=5$ for the backshore $\mathrm{BN}$ and $\mathrm{M}=3$ for the sandline $\mathrm{BN}$. These results can be downloaded from Smith and others (2017).

\section{Long-Term Estuarine-Shoreline-Change Assessment}

The BN model for long-term estuarine-shoreline change demonstrates skillful predictions of the expected shoreline change rate when hindcast testing was performed. Hindcast testing uses the same data that was used to train the model (table 3). More than 3,000 barrier-island profiles were analyzed in total, including 1,110 locations for Assateague and 2,348 locations along the New Jersey coast. Hindcast predictions show an overall skill of 0.58 . Prediction skill was slightly higher for Assateague (skill $=0.67$ ) when trained using all data (table 3). A model trained with just Assateague data and tested against Assateague showed an increased skill of 0.70, indicating that there are input constraints or shorelinechange responses that are specific to the Assateague coastline and not well generalized across the two regions. Training on and testing only New Jersey data did not change the prediction skill, indicating 
that input constraints and shoreline response are generalizable across the two regions, or indicating that the data in New Jersey dominated the training. When the BN was trained on New Jersey data and used in the Assateague prediction, the skill was 0.20, indicating that just 20 percent of the New Jersey input-response variability was similar to that of Assateague. The alternative test (train New Jersey and predict Assateague) resulted in a skill of 0.11 . We can conclude that the improved predictions using both datasets in training produces the most generalizable model because either the input constraints or the responses (or both) are not generalizable across the two regions.

Predictions also include uncertainty estimates at each point that measure the model's confidence. Using the probability of the most likely prediction as a confidence metric and setting an arbitrary threshold for "high" certainty at a probability of 0.75 , we found that 75 percent of profiles had certainties equal to or exceeding this value. (Note that the probability threshold for suitably high certainty can be set to any tolerance, depending on requirements for scientific testing or decision making. Because the output in this case could fall into one of five possible categories, a threshold of 0.2 would correspond to total uncertainty because probability would be distributed equally in all five bins.) Maps (figs. 9 and 10) show the spatial variability of the observations, predictions, and prediction certainty for the long-term estuarine-shoreline change for the Assateague (fig. 9) and part of the New Jersey study areas (fig. 10).

Table 3. Long-term and storm-driven back-barrier-shoreline-change-prediction accuracy using weighted (and unweighted) skill with independent and hindcast models in the New Jersey and Assateague study areas.

\begin{tabular}{lllllll}
\hline \multirow{2}{*}{ Calibration } & \multicolumn{5}{c}{ Testing } \\
\cline { 2 - 7 } & \multicolumn{5}{c}{ Long term (LT) } & \multicolumn{3}{c}{ Storm driven (HS) } \\
New Jersey & Assateague & Both LT and & HS & New Jersey & Assateague & Both LT and \\
New Jersey & $0.55(0.58)$ & $0.20(0)$ & & $0.52(0.21)$ & $0.09(0)$ & \\
Assateague & $0.11(0)$ & $0.70(0.67)$ & & $0.09(0)$ & $0.53(0.29)$ & \\
Both LT and HS & $0.54(0.55)$ & $0.67(0.63)$ & $0.58(0.55)$ & $0.46(0.18)$ & $0.53(0.29)$ & $0.49(0.22)$ \\
\hline
\end{tabular}

\section{Storm-Driven Estuarine-Shoreline-Change Assessment}

The BN model for storm-driven back-barrier-shoreline change produced prediction skills that were similar to long-term prediction skill values. Hindcast prediction using data from all study sites had a skill of 0.58. Predication skill was slightly higher for Assateague (0.53) than New Jersey (0.46) when model was trained on all the data (table 3). Training with both datasets did not improve the prediction skill for Assateague and slightly decreased the prediction skill for New Jersey compared to training and testing with the same data. Most predictions had either moderate $\left(0.5 \leq \mathrm{P}_{\mathrm{ml}}<0.75\right)$ or high certainty $\left(\mathrm{P}_{\mathrm{ml}} \geq 0.75\right)$, where $\mathrm{P}_{\mathrm{ml}}$ is the probability of the most likely outcome. Less than 12 percent of the profiles had low certainty $\left(\mathrm{P}_{\mathrm{ml}}<0.5\right)$. Mapped results (figs. 11 and 12) show the spatial variability in observations, predictions, and certainty. For example, at the north end of Assateague (fig. 11), the storm-driven change is negative (erosion), which is the opposite sign from the long-term trend (fig. 9). At this location, observations and predictions are in agreement for both storm-driven and long-term response.

\section{Long-Term Sandline-Change Assessment}

Overall, the skill metrics (table 4) indicate that the BN models (fig. $8 A$ and $8 B$ ) can predict both the long-term and Hurricane Sandy-induced sandline change across the Assateague and New Jersey 

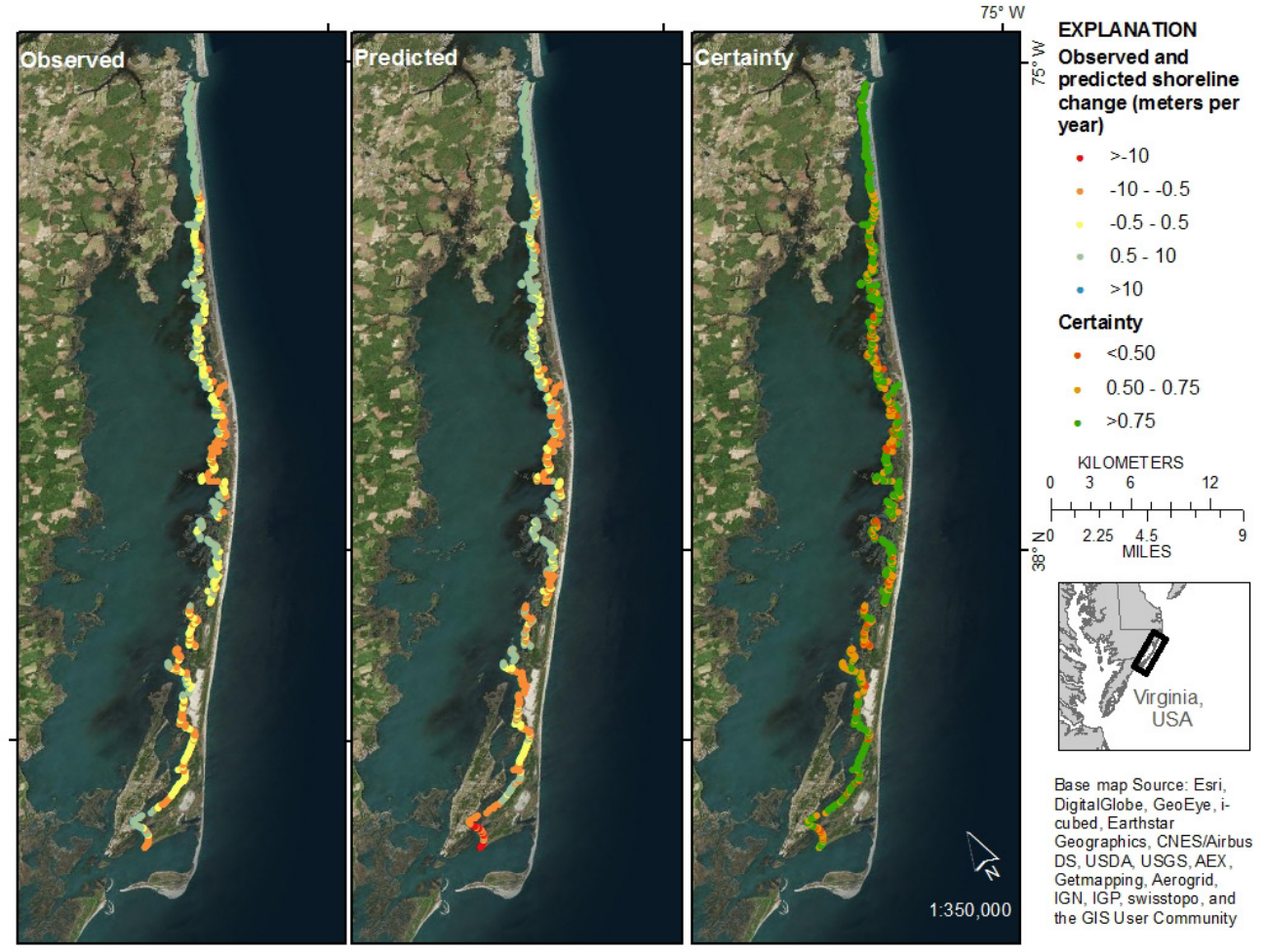

Figure 9. Maps showing the observed long-term (left panel) and predicted (middle panel) long-term estuarine-shoreline change, and prediction certainty (right panel) at Assateague Island, Maryland and Virginia. Negative values indicate an eroding estuarine shoreline.
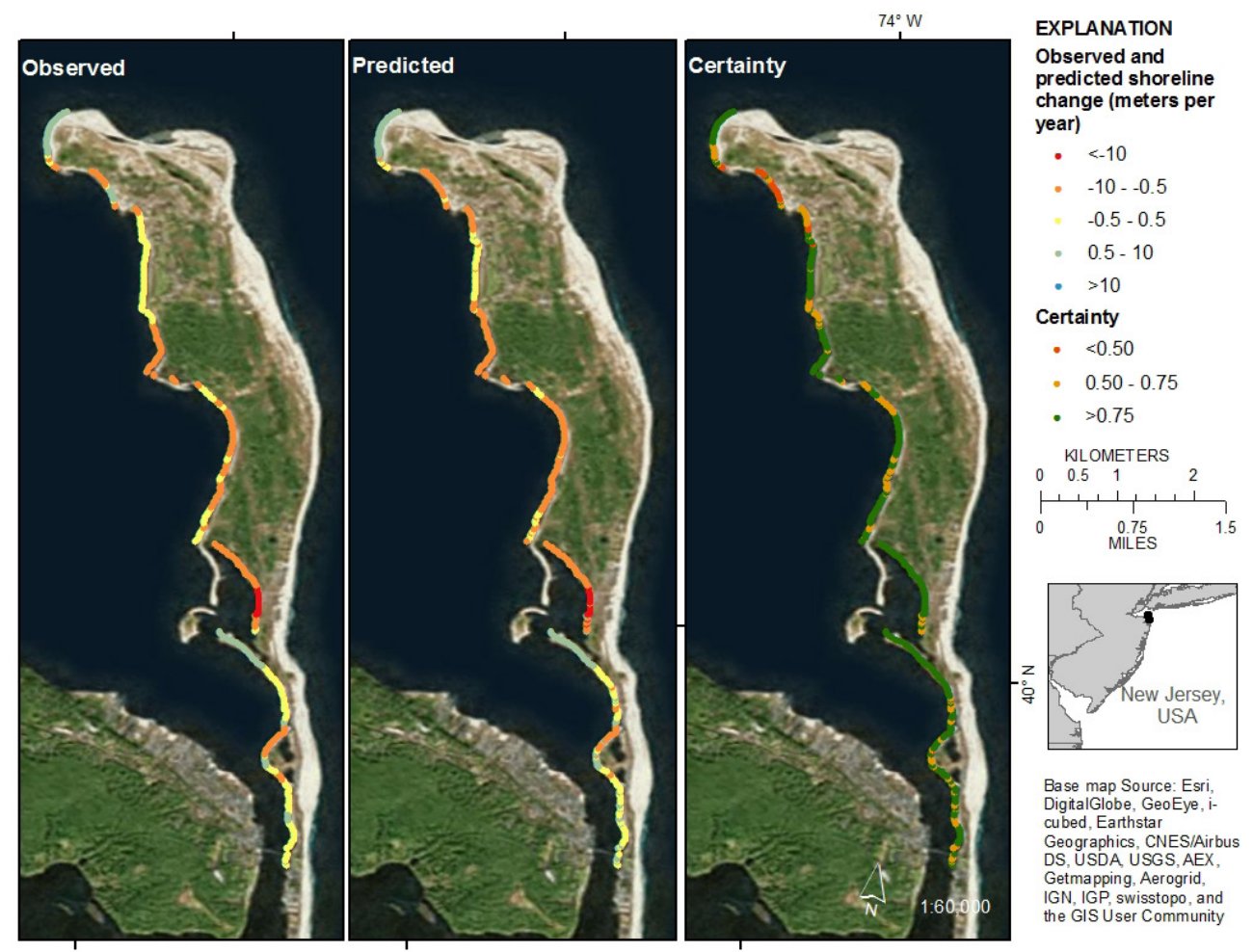

Figure 10. Maps showing the observed long-term (left panel) and predicted (middle panel) long-term estuarine-shoreline change, and prediction certainty (right panel) at Sandy Hook, New Jersey. Negative values indicate an eroding estuarine shoreline. 

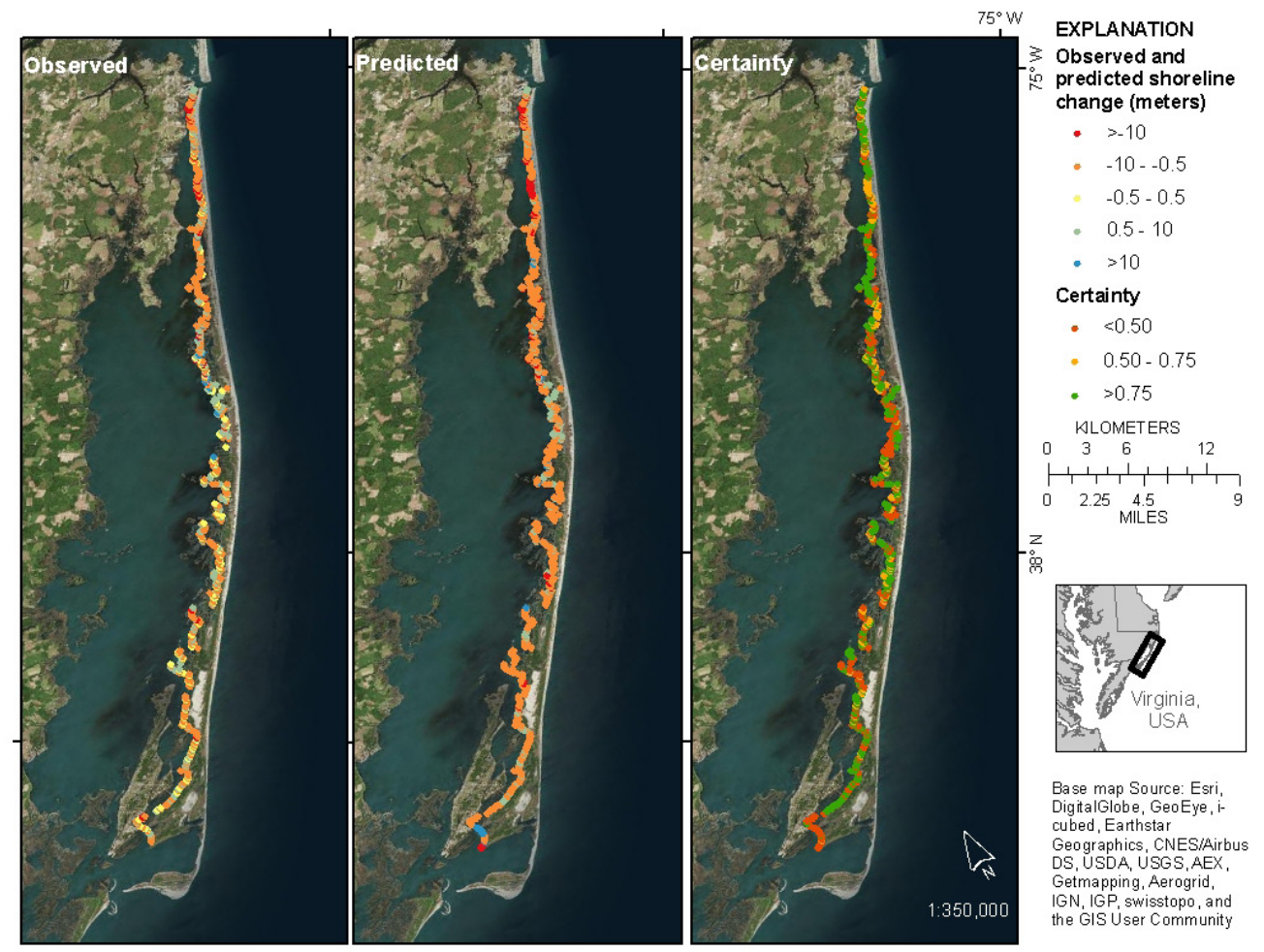

Figure 11. Maps showing the observed (left panel) and predicted (middle panel) storm-driven estuarine-shoreline change, and prediction certainty (right panel) at Assateague Island, Maryland and Virginia. Negative values indicate storm-driven estuarine-shoreline erosion.

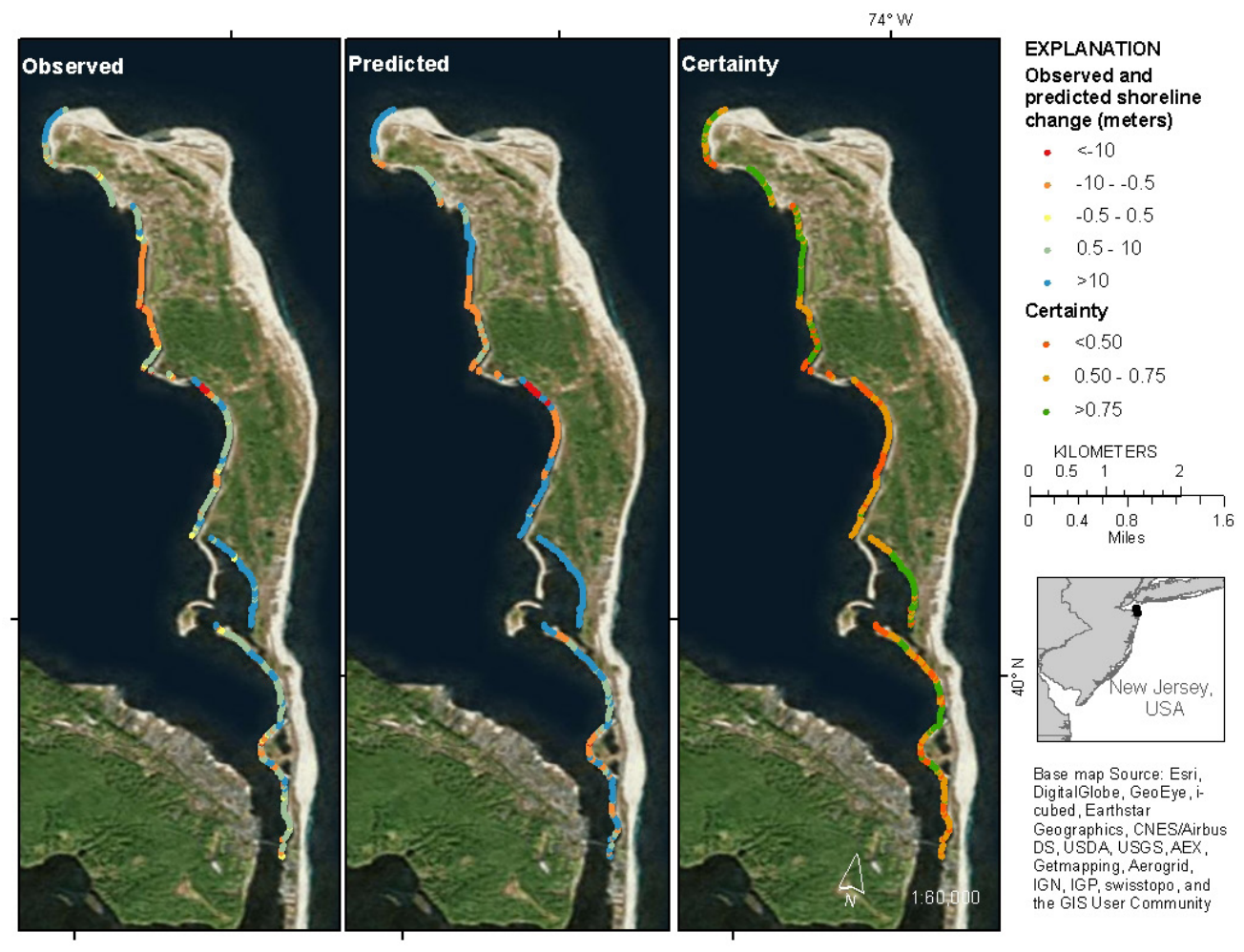

Figure 12. Maps showing the observed (left panel) and predicted (middle panel) storm-driven estuarine-shoreline change, and prediction certainty (right panel) at Sandy Hook, New Jersey. Negative values indicate storm-driven estuarine-shoreline erosion. 
domains. As with the shoreline-change results, the output from the long-term sandline change BN can be mapped at each location to show observed long-term sandline change, predicted long-term sandline change (most probable prediction), and certainty (figs. 13 and 14). For example, the results at Sandy Hook, New Jersey (fig. 14), show broad agreement between predictions and observations of the spatial trends of long-term sandline change due to repeated overwash in the northern and southern regions. Positive sandline change, indicating that the sandline is moving seaward, occurs in the central region. Seaward movement typically reflects a long-term increase in vegetation, perhaps in response to a large storm occurring near the beginning of our analysis period, or in response to coastal management that could include dune planting or beach nourishment. Landward sandline movement typically corresponds to progressive overwash and open-coast shoreline-erosion events that push the barrier island as a whole in the landward direction. The predictions in the New Jersey region have moderate certainty, indicating that long-term sandline change is more complex than estuarine-shoreline change. The skill metrics for the long-term sandline change (0.65) are about 20 percent higher than the shoreline-change skills, indicating that lower certainty does not result in an overall reduction in accuracy. In the Assateague study area, predictions overestimate the magnitudes of change, where there was too much sandline retreat and advance. Nonetheless, the regions of advance or retreat were accurately identified by the predictions. Prediction uncertainty was mostly moderate to high in this study region. This might indicate that the BN model was somewhat overfit to the data, explaining the occurrence of an overconfident prediction of excessive sandline advance or retreat.

Table 4. Skill with independent and hindcast models for Skill metrics Sandline Change Bayesian Network output.

\begin{tabular}{ccc}
\hline & $\begin{array}{c}\text { Predict long-term } \\
\text { sandline change }\end{array}$ & $\begin{array}{c}\text { Predict storm-driven } \\
\text { sandline change }\end{array}$ \\
\hline Skill & 0.65 & 0.74 \\
\hline
\end{tabular}

\section{Storm-Induced Sandline-Change Assessment (Storm Driven)}

Hurricane Sandy-induced sandline-change predictions (figs. 15 and 16) are predicted with higher skill than the long-term sandline changes (table 4). The mapped BN output matches the observed dominance of landward movement (typically exceeding 10 meters) of the storm-induced sandline change in the Assateague region, where overwash was prevalent, as was documented by others (Sopkin, 2014), and vegetation was buried or eroded or both occurred. In the Sandy Hook, New Jersey region, the BN accurately predicts more overwash in the northern region, but the confidence in the predictions is low to moderate at nearly all locations (fig. 16). This indicates that while the most likely prediction is consistent with the observations (skill of 0.74 , table 4 ), variability in the actual response across both study regions is predicted as well. Inspection of the underlying data and imagery indicated that in some areas, the demarcation of the sandlines where the vegetation was sparse was itself a noisy estimate. For instance, the southern portion of Sandy Hook (fig. 16) was observed and predicted to have seaward sandline movement, indicating vegetation growth. This section of coast was unusually wide and was sparsely vegetated before and after Hurricane Sandy, contributing to low predictive uncertainties. This noise is included in the BN training and reduces the prediction uncertainties. At Assateague, the BN predicts the dominance of overwash (sandline retreat), consistent with the observations but with a slightly lower skill (0.65) than the predictions for the New Jersey coastline. There is variability in the certainty, which is moderate at the two ends of the island and low along the central section of the study area. 

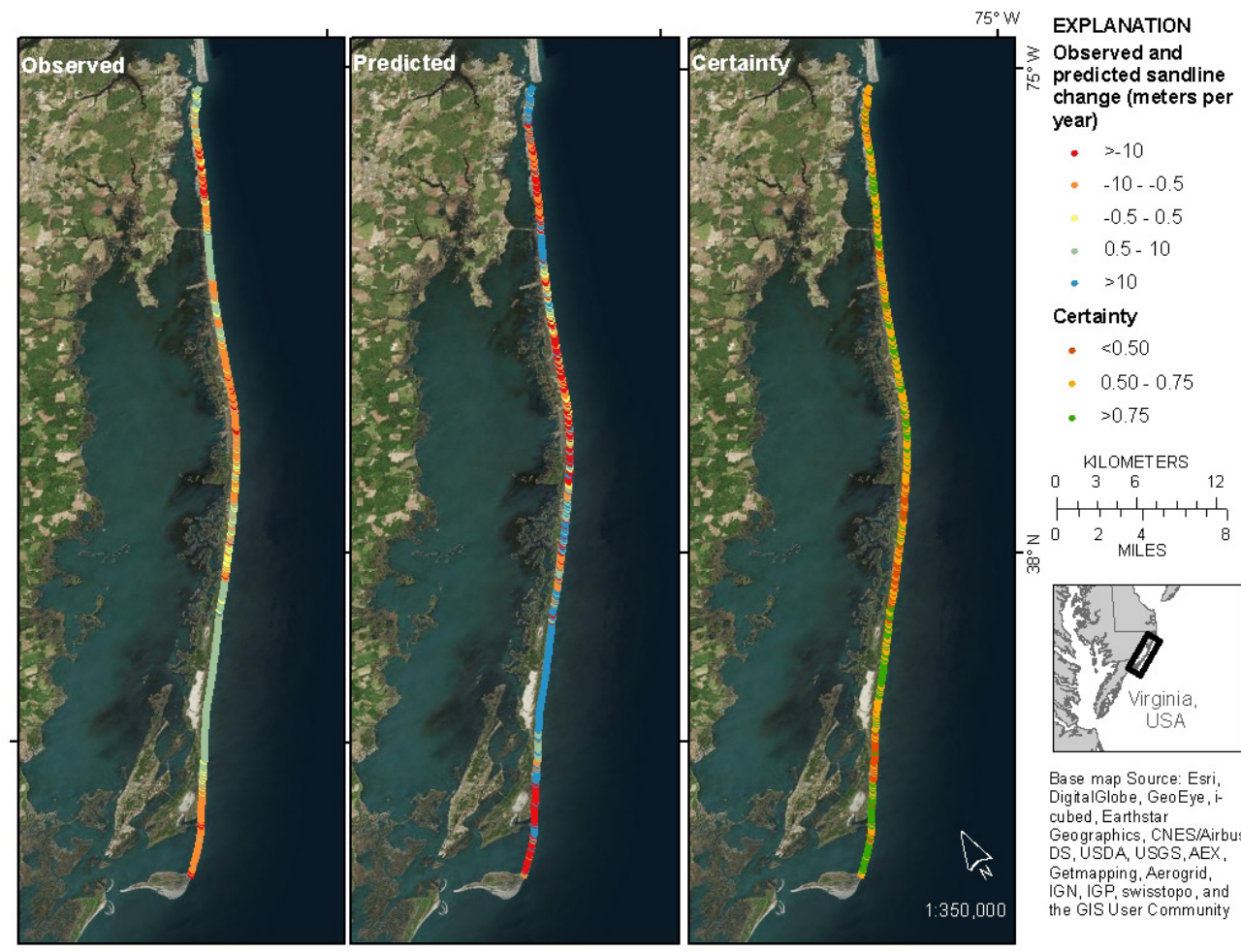

Base map Source: Esri, DigitalGlobe, GeoEye,

cubed, Earthstar

Geographics, CNES/Airbu

DS, USDA, USG S,AEX

Getmapping, Aerogrid,

the GIS User Community

Figure 13. Maps showing the observed (left panel) and predicted (middle panel) long-term sandline change, and prediction certainty (right panel) at Assateague-Island, Maryland and Virginia. Positive sandline change values indicate seaward-directed movement.

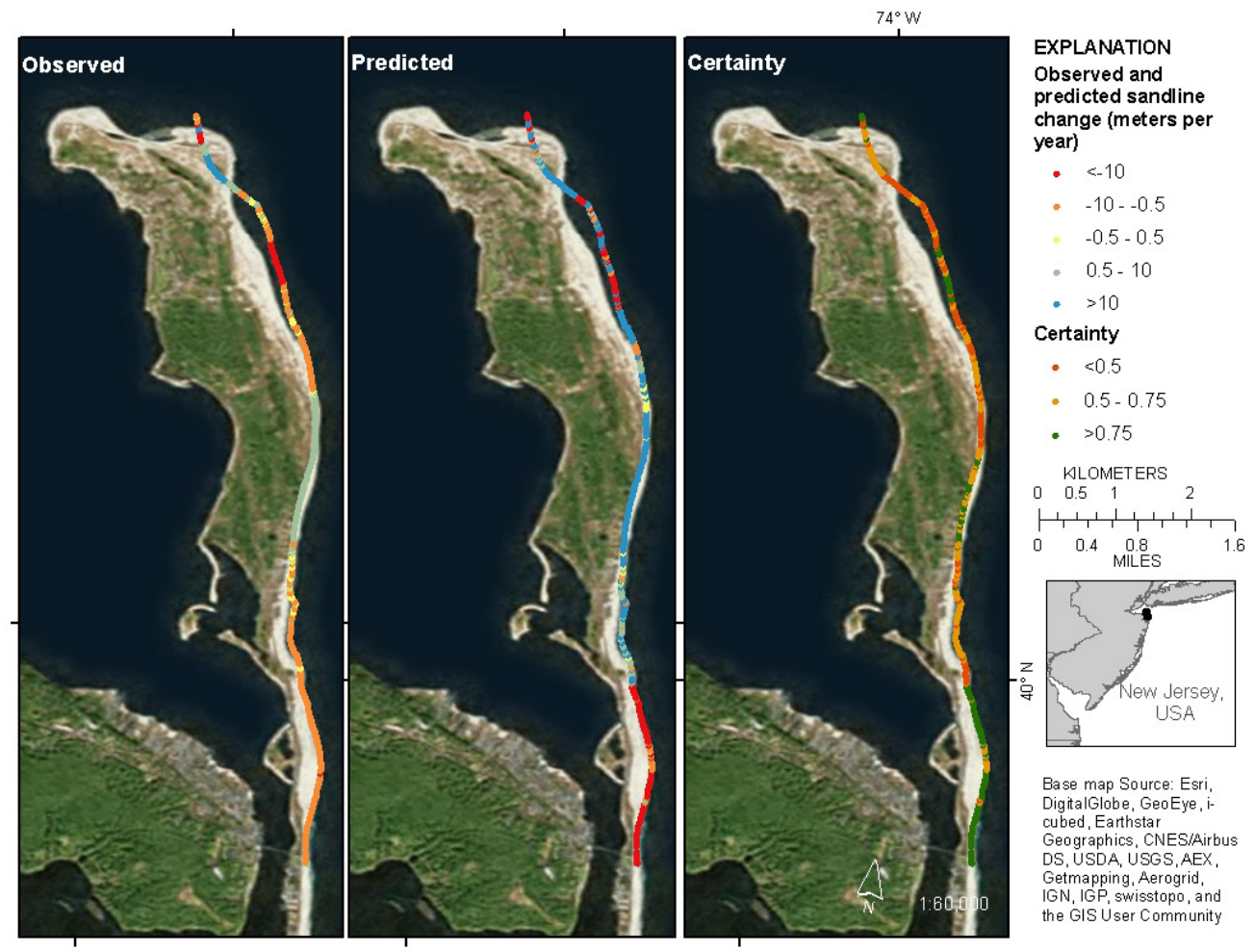

Figure 14. Maps showing the observed (left panel) and predicted (middle panel) long-term sandline change, and prediction certainty (right panel) at Sandy Hook, New Jersey. Positive sandline-change values indicate seaward-directed movement. 

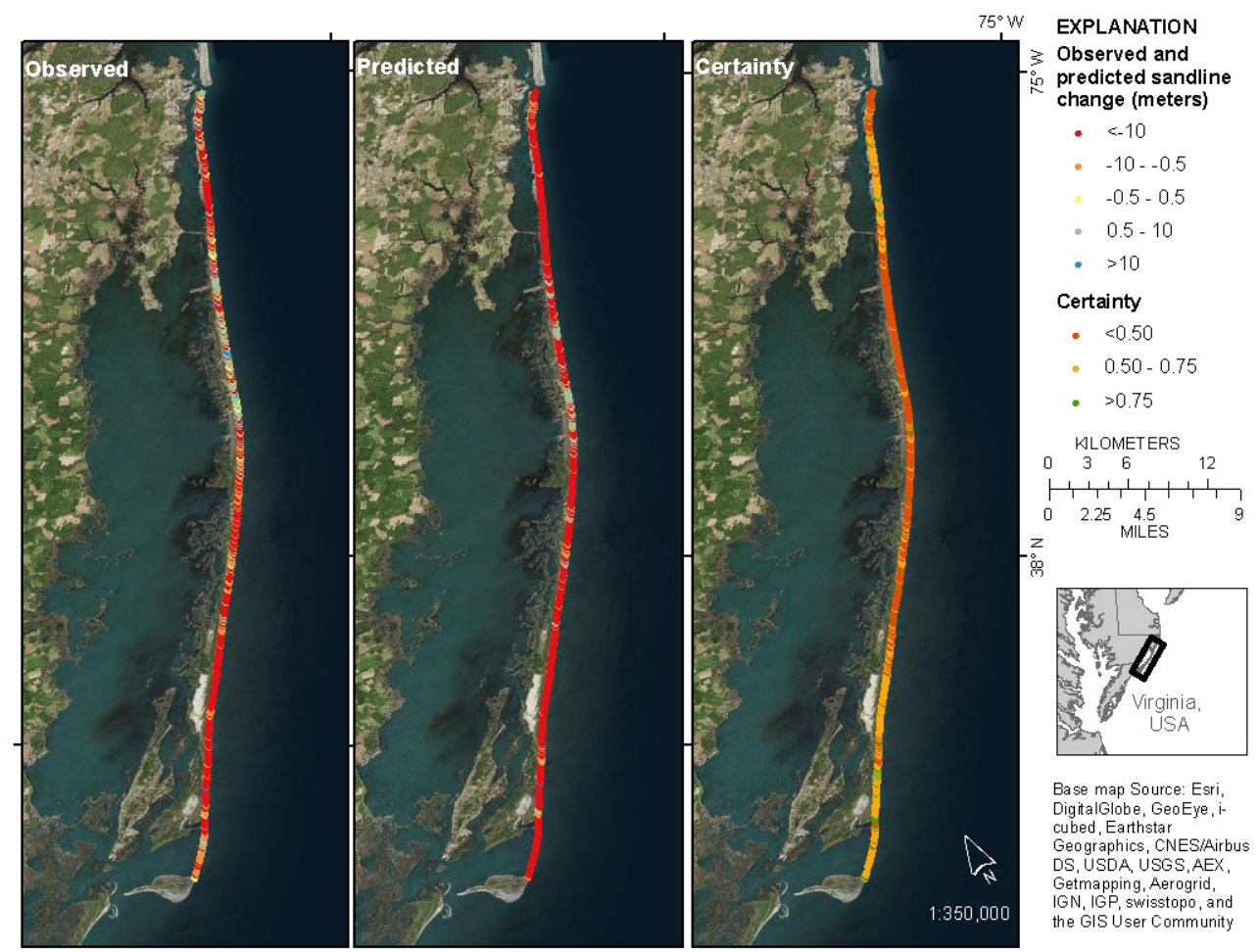

Figure 15. Maps showing the observed (left panel) and predicted (middle panel) storm-induced sandline change, and prediction certainty (right panel) at Assateague Island, Maryland and Virginia. Positive sandline-change values indicate seawarddirected movement.

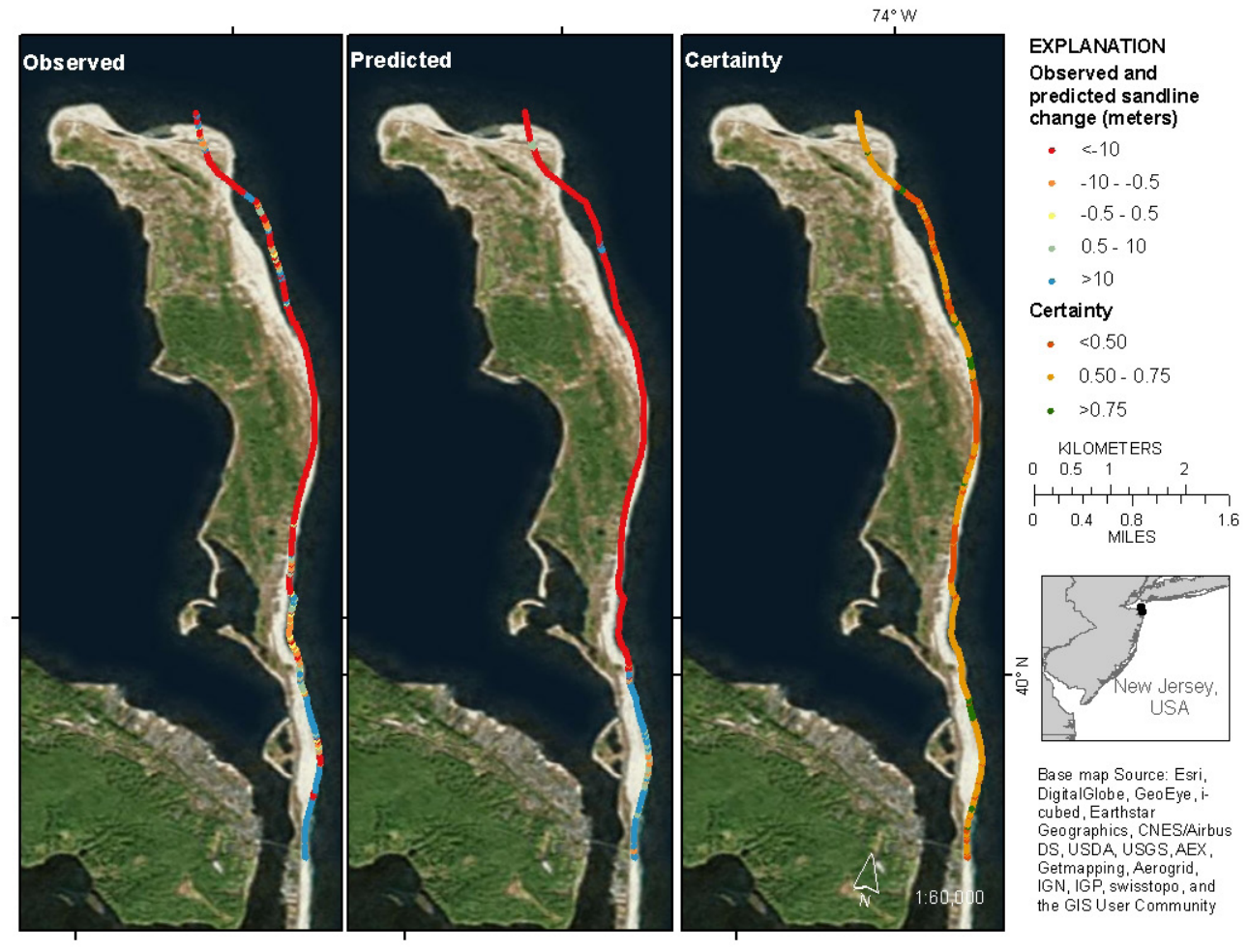

Figure 16. Maps showing the observed Hurricane storm-induced sandline change (left panel), predicted Hurricane Sandyinduced sandline change (middle panel), and prediction certainty (right panel) at Sandy Hook, New Jersey. Positive sandline change values indicate seaward-directed movement. 


\section{Wetland-Shoreline Ecological-Change Assessment}

The result of the wetland shoreline ecological-change assessment, which is based on the observed long-term changes in vegetation, documents both wetland formation and destruction behind barrier islands (figs. 17 and 18). At Assateague (fig. 17), imagery and sandline data show the continuum of marsh maturity proposed by Smith and others (2015), ranging from wetlands persisting through multiple image sets to recent wetlands emerging between image sets reflecting colonization of recent breaches and overwash. Only at the narrow northern end of the island is burial of historic wetlands prevalent where the long-term estuarine shoreline had accreted (built into the estuary, fig. 9), indicating loss of some wetlands. The historic land cover in this region had a mix of bare sand (land) and wetlands, so the persistent accretion not only buried old wetlands, but also formed regions where vegetation could grow. At Long Beach Island (fig. 18), ecological-change data show a similar continuum between mature and young marsh. Here, the southern half of the study area highlights the emergence of a young marsh on a pre-1880 barren region. In contrast, the north portion of Long Beach Island had wetlands present pre1880 that either persisted through time or were buried by sand.

\section{Discussion}

Assessments of physical changes in barrier islands and associated wetlands have been conducted that describe impacts of Hurricane Sandy and long-term changes. These assessments include analysis data derived primarily from remotely sensed imagery that was sufficient to document the evolution of open-ocean and estuarine shorelines and the evolution of the sand-vegetation boundary associated with the landward extent of overwash deposits. Model predictions of storm-driven and long-term impacts to these features were developed to explain spatial variations in evolution and to provide a means to extend what was learned through Hurricane Sandy to the future. This extension depends on understanding the connection between the remotely sensed features and their evolution to on-the-ground impacts and implications, such as the change in land cover as discussed in the previous section. It is possible that extension to future applications and analyses at other locations could benefit with new remote-sensing methods. This discussion addresses (1) the relation between our remote-sensing-based assessments and corresponding in situ observations of barrier-island evolution, (2) the use of other remote-sensing methods, and (3) a strategy for continued application of our approach.

\section{Physical Process Interpretations}

Model-based assessments in the estuarine shoreline and the sandline are capable of capturing much of the detail resolved by the observation-based assessment. For example, the extent of sandline change due to Hurricane Sandy shows spatial variability that is controlled by a combination of island width and height. The impact of overwash processes on the estuarine shoreline in the long term and short term result in accumulation of sediments that are important for both geomorphic and ecosystem resilience in the future. For example, the thickness of Hurricane Sandy overwash deposits (table 5) was similar at the northern (transect 1, fig. 4) and southern (transect 4, figs. 4 and 5) locations; however, the cumulative thicknesses of overwash deposits are greater at transect 1 (Bernier and others, 2016; Zaremba and others, 2016a), where overwash deposits reached the estuary and extended the position of the shoreline. Geologic analysis shows that some of the overwash deposits included in the Hurricane Sandy analysis are actually attributed to multiple storms, and this is corroborated by the imagery at both Assateague and New Jersey locations (Bishop and others, 2016b; Zaremba and others, 2016a). Where changes in the sandline do not reach the estuarine shoreline, overwash deposits contribute to elevation 

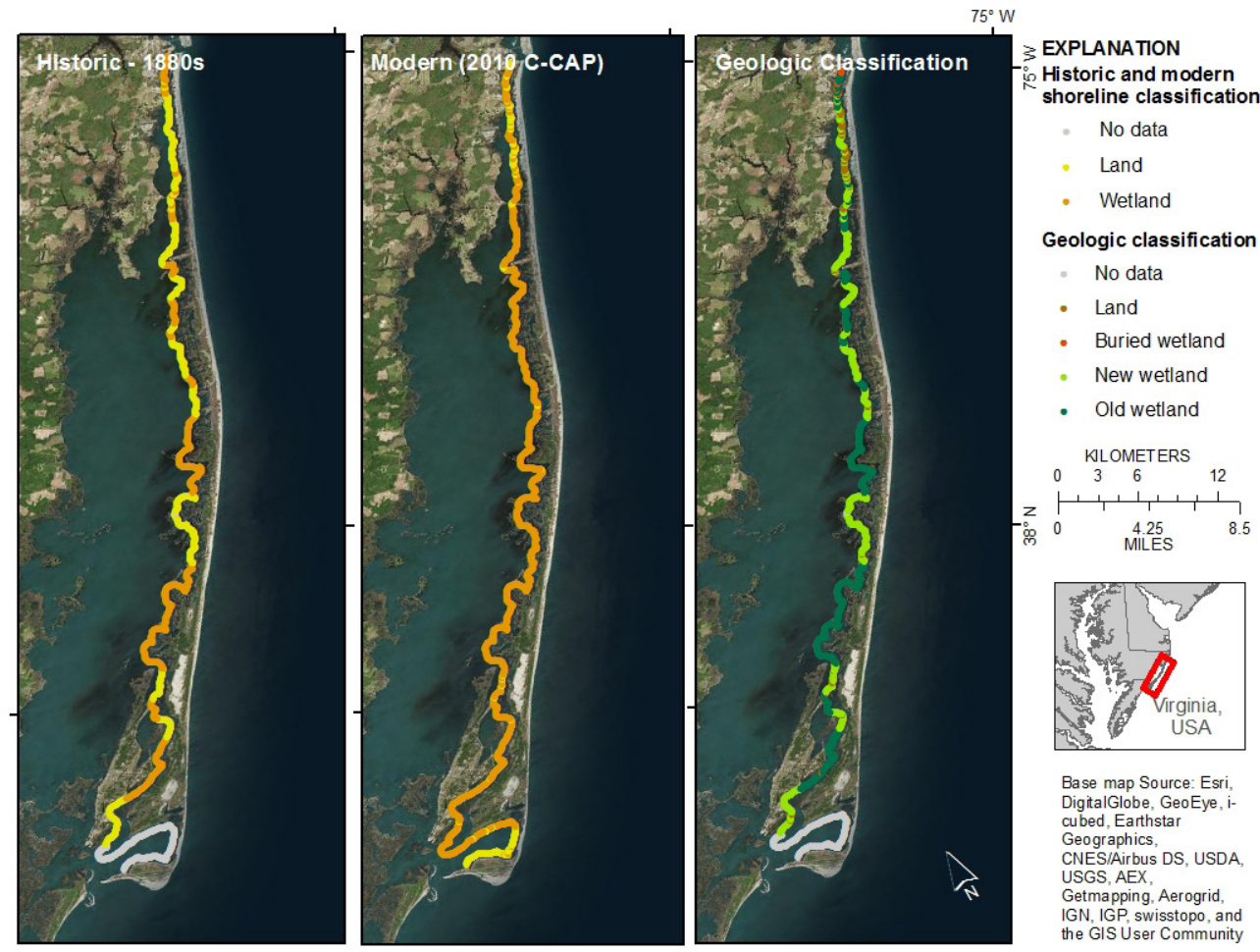

Figure 17. Maps showing assessment of back-barrier-shoreline type based on historical data (left panel) and recent data (middle panel) at Assateague Island, Maryland and Virginia. Changes are used to show wetland transformations or stability in terms of a geologic classification (right panel).
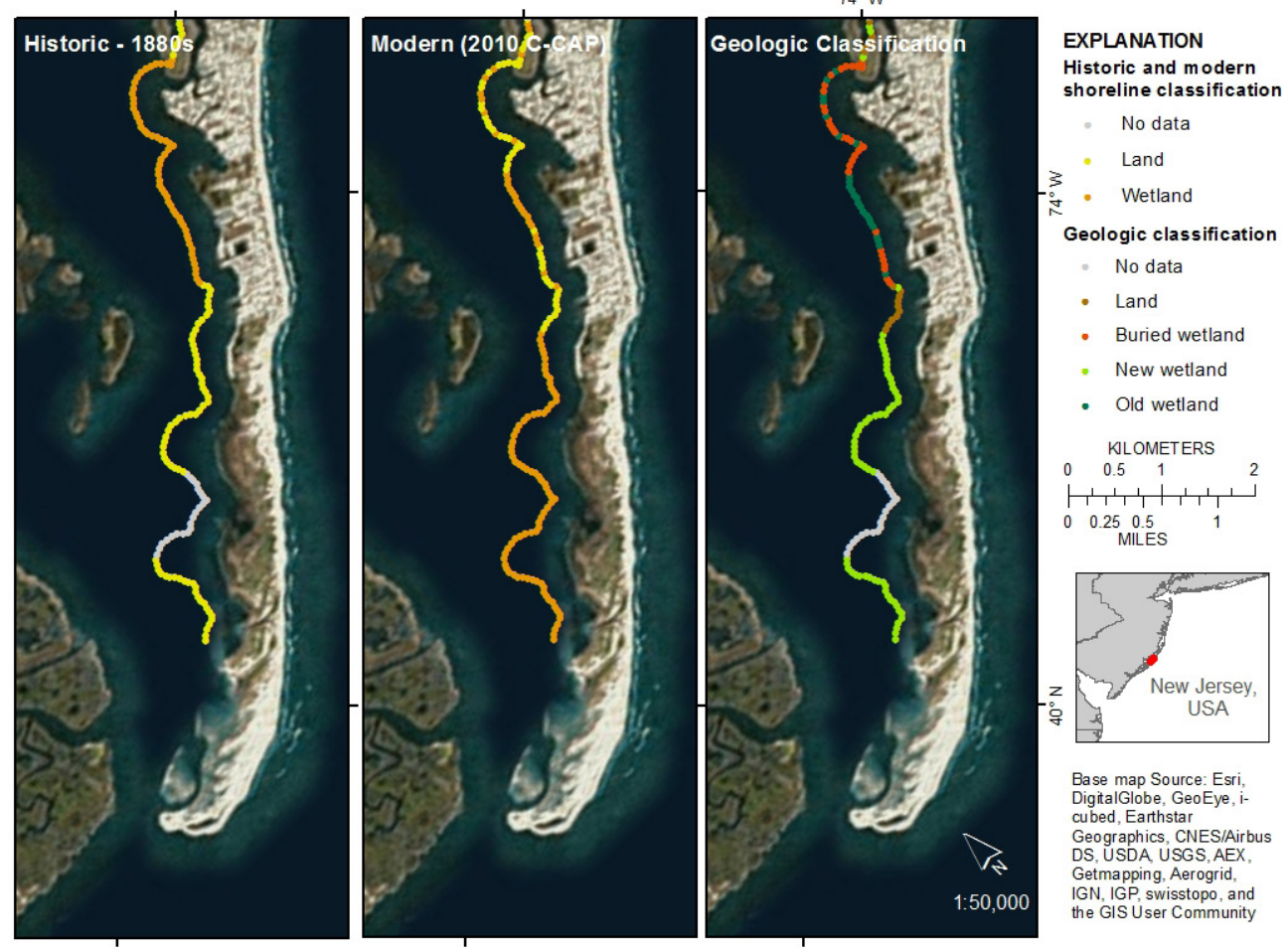

Figure 18. Maps showing assessment of back-barrier-shoreline type at Long Beach, New Jersey, based on historical data (left panel) and recent data (middle panel). Changes are used to show wetland transformations or stability in terms of a geologic classification (right panel). 
gains in the island interior. Geologic GPR assessments across the island from uniquely document this elevation gain in areas that were either too low or too vegetated to be measured quantitatively by other means, such as from lidar surveys (Zaremba and others, 2016a).

The in situ geologic observations can be used to quantify both the amount and characteristics of sediment deposits that correspond to the changes in shorelines and sandlines. The contributions of inorganic material may add to or be the only contribution to the elevation budget of the barrier and its wetlands. The inorganic contribution distinguishes two marsh types. At type 1 sites, accretion rates are high due to the inorganic sediment deposition from overwash and aeolian processes (Bishop and others, 2016b). One core (14CTB-14M, table 5), obtained from what we consider to be type 1 marshes (fig. 17), provided reliable chronology. For this core, the linear sedimentation (vertical accretion) rate inclusive of inorganic sediment layers was 0.8 centimeter $(\mathrm{cm}) \mathrm{y}-1(\sim 0.8 \mathrm{~g}$ [gram] cm-2 y-1) with inorganic sediment layers constituting an estimated 60 to 70 percent of the total accumulation.

Type 2 marshes had LSRs that were lower $(0.41 \pm 0.11 \mathrm{~cm} \mathrm{y}-1)$ than the type 1 and transition marshes. In contrast, when only the organic-rich sections were considered (that is, excluding episodic inorganic deposition), the average vertical accretion was quite uniform for all sites $(0.24 \pm 0.05 \mathrm{~cm} \mathrm{y}-1)$. This accretion rate is slightly below the 60-year relative sea-level trend observed at Kiptopeke, Virginia $(0.36 \pm 0.03 \mathrm{~cm} \mathrm{y}-1)$, and the 30 -year relative sea-level trends of $0.56 \pm 0.10$ and $0.54 \pm 0.09 \mathrm{~cm} \mathrm{y}-1$

Table 5. Constant flux and sedimentation model results for the cores.

[cm, centimeters; $\mathrm{n}$, number of samples; $\mathrm{r}^{2}$, coefficient of determination; MAR, mass accumulation rate; MAR estimate, g cm-2 y-1; MAR error, standard error (g cm-2 y-1); LSR, linear sedimentation rate; LSR estimate, $\mathrm{cm}$ y-1; LSR error, standard error (cm y-1)]

\begin{tabular}{|c|c|c|c|c|c|c|c|}
\hline Core ID & Depth (cm) & $\mathrm{n}$ & $r^{2}$ & MAR estimate & MAR error & LSR estimate & LSR error \\
\hline \multicolumn{8}{|l|}{ Type 1 marshes } \\
\hline 14CТВ-04M & $0-5$ & 5 & 0.817 & 0.05 & 0.01 & 0.09 & 0.01 \\
\hline 14CTB-04M* & $0-5,30-36$ & 11 & 0.871 & 0.07 & 0.01 & 0.12 & 0.02 \\
\hline 14CTB-11M & $0-5$ & 5 & 0.942 & 0.03 & 0.00 & 0.07 & 0.00 \\
\hline 14CTB-14M & $0-38$ & 38 & 0.553 & 0.79 & 0.12 & 0.79 & 0.09 \\
\hline $14 \mathrm{CTB}-14 \mathrm{M}^{*}$ & $0-6,19-26$ & 13 & 0.308 & 0.23 & 0.10 & 0.33 & 0.09 \\
\hline \multicolumn{8}{|l|}{ Transition } \\
\hline 14CTB-06M & $0-34$ & 34 & 0.671 & 0.57 & 0.07 & 1.00 & 0.05 \\
\hline 14CTB-06M* & $0-1,7-11,20-34$ & 19 & 0.883 & 0.19 & 0.01 & 0.18 & 0.01 \\
\hline \multicolumn{8}{|l|}{ Type 2 marshes } \\
\hline 14CTB-13M & 0-32 & 32 & 0.519 & 0.13 & 0.02 & 0.54 & 0.03 \\
\hline 14CTB-13M* & $0-3,10-32$ & 25 & 0.531 & 0.10 & 0.02 & 0.23 & 0.01 \\
\hline 14CTB-25M(A) & $0-23$ & 23 & 0.492 & 0.08 & 0.02 & 0.44 & 0.10 \\
\hline 14CTB-25M(A)* & $0-13,17-23$ & 19 & 0.615 & 0.05 & 0.01 & 0.30 & 0.05 \\
\hline 14CTB-25M(B) & $0-18$ & 18 & 0.800 & 0.06 & 0.01 & 0.26 & 0.03 \\
\hline $14 \mathrm{CTB}-25 \mathrm{M}(\mathrm{B}) *$ & $0-12,15-19$ & 15 & 0.780 & 0.04 & 0.01 & 0.20 & 0.03 \\
\hline
\end{tabular}

*Indicates samples analyzed without sand.

For procedure, reference Smith and others (2013); Smith and others (2015). 
observed at Ocean City Inlet, Maryland, and Wachapreague, Virginia, respectively. In comparison, work by Zaremba and others in the more interior portion of the island showed that composite overwash deposition from Hurricane Irene and Hurricane Sandy $(10-50 \mathrm{~cm})$ would be equivalent to 40 to 200 years of vertical marsh accretion from organic matter accumulation. The additional inorganic sediment supplied by overwash is thus inferred to aid in the maintenance of elevation of these back-barrier marshes. This inorganic contribution allows the marshes to keep up with sea-level rise.

\section{Alternate Approaches to Extending Remote-Sensing Observations Using Satellite Data}

Observationally based and the model-based and barrier-island estuarine-wetland physicalchange assessments rely on remote-sensing methods that can be applied to aerial or satellite imagery in order to derive variables required to develop or update barrier-island and wetland assessments in the future. Specifically, we require that both long-term and storm-event changes in shorelines and sandlines to be resolved by the remote-sensing data and methods. Comparison of the results from the aerial imagery (fig. 19A; Guy, 2015a, c) and satellite analyses ( fig. 19B; Bernier and others, 2015) illustrates similarities and minor differences in details and location of sandlines and shorelines (fig. $19 C$ ) due to changes in resolution and sensor properties. However, there are advantages in using the lower resolution satellite imagery that are well suited to automated land cover classification analysis (fig. 3), which is required for sandline detection, and Landsat images are acquired much more frequently than higher resolution aerial imagery. Because our assessment methods are framed statistically as either a linear regression estimation or $\mathrm{BN}$, there is no intrinsic reason to exclude additional data sources just because they have reduced resolution, and we conclude that we could utilize Landsat imagery effectively.

\section{Future Applications}

Assessment of estuarine-shoreline and sandline change at two timescales can be related to existing assessments of the open-ocean shoreline and dunes. Specifically, the existing open-ocean long-term shoreline-change data (Himmelstoss and others, 2010) were used as an input to predictions of both estuarine-shoreline- and sandline-change assessments. Oceanographic drivers from existing dune vulnerability assessments (Doran and others, 2012) were used as inputs to the prediction of changes associated with Hurricane Sandy's landfall. Thus, the value of the model-based over the observation-based assessment is that future scenarios, where the input variables may be altered, can be examined. These future scenarios could include short-term (days) forecasts of approaching storms to support storm-impact response, as well as exploring hypothetical scenarios to support longer term planning purposes. This capability provides a way to test new hypotheses and improve our broad understanding of the evolution of coastal systems from the ocean to estuaries. Furthermore, the model structure provides a tool for assessing future resilience and sustainability. Assessments of future conditions could incorporate resource management plans that alter parts of the barrier-island systems, demonstrating the impact on the broader system as it responds to storms and sea-level rise.

Barrier islands and their associated wetlands, interior habitat, and shorelines will keep changing, either gradually or episodically. This means that coastal land managers will need to continue to adapt their management plans and make short-term and long-term decisions that respond to actual or expected changes. Our observational and analysis effort demonstrates a capability that can be maintained in the existing locations to provide updates on actual shoreline, sandline, and geological characteristics, as 

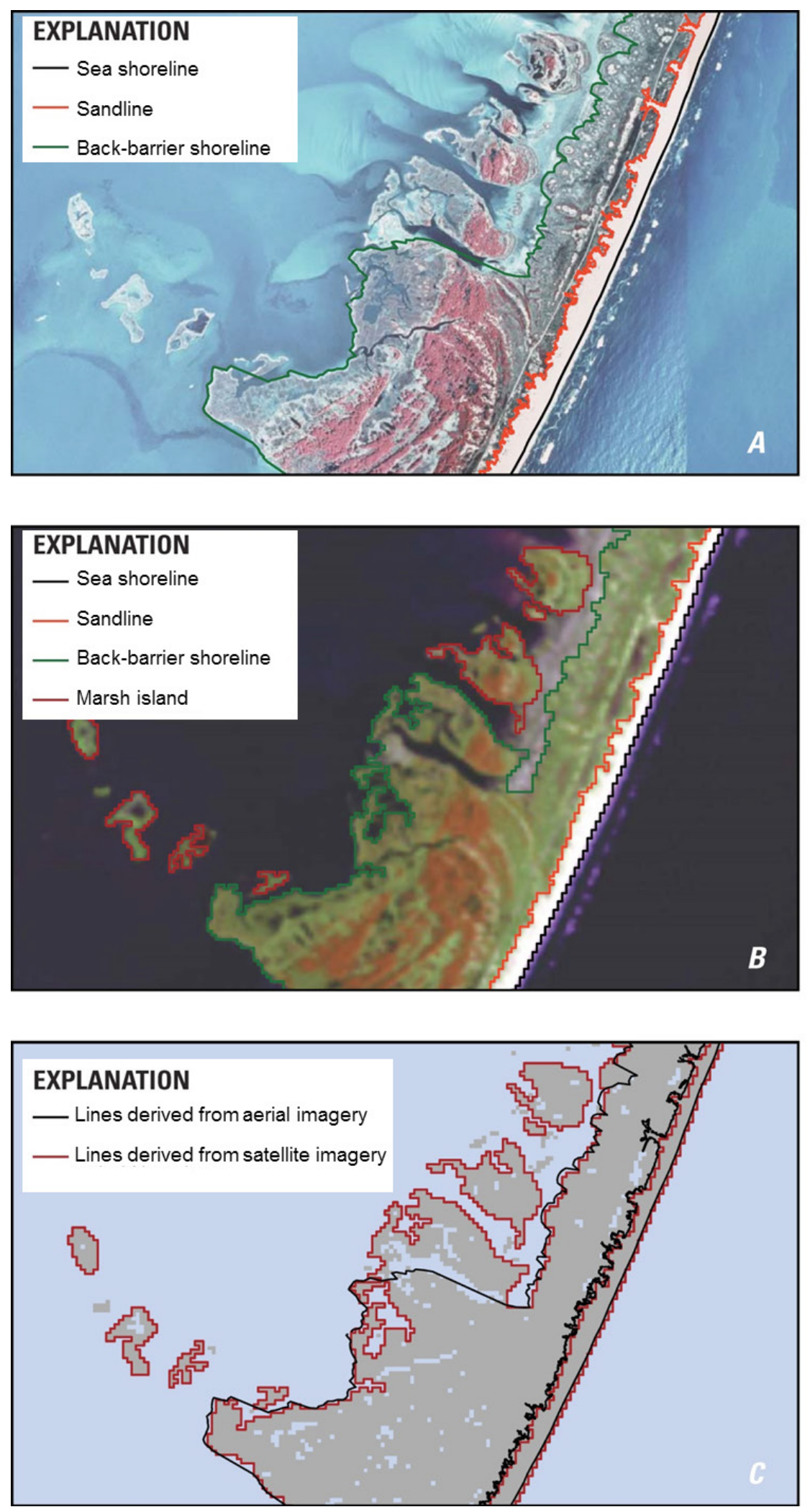

Figure 19. Imagery, shorelines, and sandlines derived from $(A)$ aerial (1-m resolution) and $(B)$ satellite (30-m resolution) sources, and comparison $(C)$ of digitized sandlines and shorelines. Image sources are $(A)$ color-infrared digital orthophoto quarter quadrangle (DOQQ) imagery acquired April 12, 1989, and (B) Landsat 5 imagery acquired April 28, 1989. 
well as to update model prediction accuracy and applicability. The capability can also be applied at other barrier-island locations, creating consistent and relevant guidance to address problems that are common across many barrier-island systems. The requirements for maintaining or extending this capability are the following:

- new data to provide updates on actual changes and to test existing models (fig. 20, top);

- research and data targeted at improving prediction accuracy (fig. 20, middle);

- research to identify where insufficient model accuracy and/or insufficient process understanding limits the applicability of predictions (fig. 20, middle); and

- updated models that are more accurate and more applicable to landscape management (fig. 20, bottom).

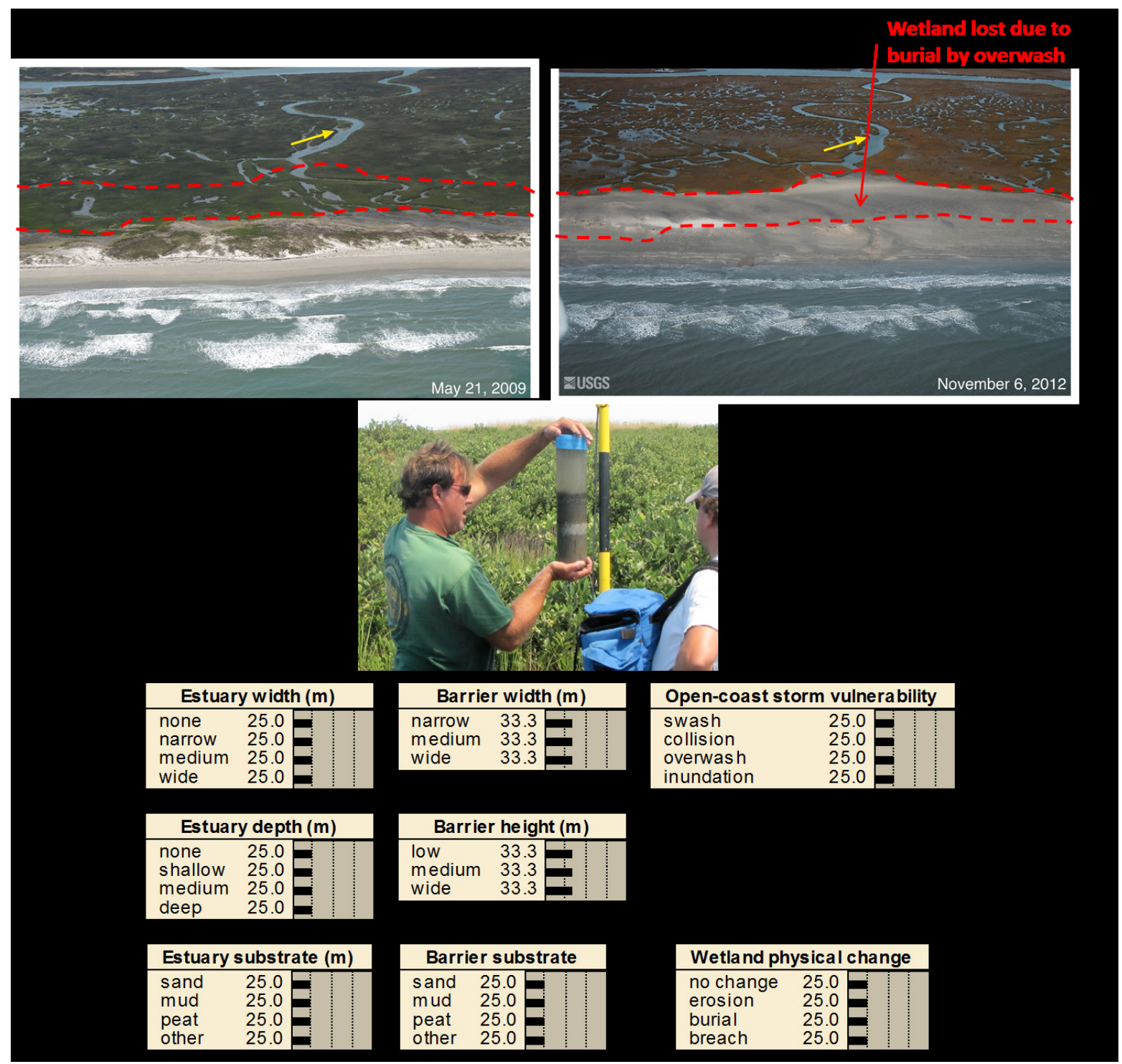

Figure 20. Elements required to maintain and extend barrier-island estuarine-wetland physical-change analysis include updated observations of changes in features (top), associated data to tie these changes to physical processes (middle), and updated models that address coastal management decisions (bottom) (m, meter). 


\section{Conclusions}

An assessment for estuarine-shoreline and barrier-island-sandline change along the Virginia, Maryland, and New Jersey coasts has been completed, documenting both the impacts of Hurricane Sandy and the long-term changes, which includes the impacts of past storm events. We demonstrated that observational data can be assimilated into predictive models that demonstrate the important interconnections between ocean-facing, barrier interior, and estuarine response to long-term processes and storms. Improved understanding of what processes are important in these interconnections has been interpreted through comparison to geologic data that resolve the actual events and processes responsible for the observed changes in the barrier-island features. A variety of remote-sensing data sources can be utilized to develop or update estuarine-shoreline and barrier-island-sandline assessments. It is likely that future expansions of this approach will utilize coarser resolution, but frequently sampled, Landsat imagery because of the applicability of objective methods to classify land cover types and estuarine features.

This effort has produced data and analysis that have been made broadly available through previous publications, including the following:

- remotely sensed measures of shorelines and barrier-island-sandline history from the past several decades through the period immediately following Hurricane Sandy's landfall (Bernier and others, 2015; Guy, 2015c, d);

- sediment cores and sedimentary and geophysical analysis to extract sediment and depositional properties (Smith and others, 2015; Bishop and others, 2016b; Zaremba and others, 2016a);

- observationally based assessment of long-term and short-term changes in estuarine shorelines and barrier-island sandlines (this report); and

- model-based assessment of long-term and short-term changes in estuarine shorelines and barrierisland sandlines (this report).

The estuarine-shoreline and barrier-island-sandline assessments extend two approaches developed previously that assessed the long-term change in the ocean-facing shoreline (Himmelstoss and others, 2010) and the response of coastal dunes to extreme storms (Doran and others, 2012). Because the new approach shares some of the same drivers for assessing storm response, it is possible to integrate this new approach with the existing assessments. Doing so would provide a new decision-support tool that could be used to guide restoration activities and assess vulnerability and resilience of ecosystems and communities that depend on barrier islands and their estuaries for coastal protection, recreation, and commerce. This could help achieve broader national objectives of the U.S. Geological Survey to serve "the Nation by providing reliable scientific information to describe and understand the Earth; minimize loss of life and property from natural disasters; manage water, biological, energy, and mineral resources; and enhance and protect our quality of life" (Buxton and others, 2013). 


\section{References Cited}

Aretxabaleta, A.L., Butman, Bradford, and Ganju, N.K., 2014, Water level response in back-barrier bays unchanged following Hurricane Sandy: Geophysical Research Letters, v. 41, p. 3163-3171. [Also available at https://doi.org/10.1002/2014GL059957.]

Bernier, J.C., Douglas, S.H., Terrano, J.F., Barras, J.A., Plant, N.G., and Smith, C.G., 2015, Land-cover types, shoreline positions, and sand extents derived from Landsat satellite imagery, Assateague Island to Metompkin Island, Maryland and Virginia, 1984 to 2014: U.S. Geological Survey Data Series 968, accessed April 1, 2017, at https://doi.org/10.3133/ds968.

Bernier, J.C., Zaremba, N.J., Wheaton, C.J., Ellis, A.M., Marot, M.E., and Smith, C.G., 2016, Sedimentologic characteristics of recent washover deposits from Assateague Island, Maryland: U.S. Geological Survey Data Series 999, accessed April 1, 2017, at https://doi.org/10.3133/ds999.

Birchler, J.J., Stockdon, H.F., Doran, K.S., and Thompson, D.M., 2014, National assessment of hurricaneinduced coastal erosion hazards - Northeast Atlantic Coast: U.S. Geological Survey Open-File Report 2014-1243, 36 p. [Also available at https://doi.org/10.3133/ofr20141243.]

Bishop, J.M., Richmond, B.M., Zaremba, N.J., Lunghino, B.D., and Kane, H.H., 2016a, Hurricane Sandy washover deposit data from southern Long Beach Island, New Jersey - Grain-size, elevations, and graphic core logs: U.S. Geological Survey data release, accessed April 1, 2017, at https://doi.org/10.5066/F7PK0D7S.

Bishop, J.M., Richmond, B.R., Zaremba, N.J., Lunghino, B.D., and Kane, H.K., 2016b, Hurricane Sandy washover deposits on southern Long Beach Island, New Jersey: U.S. Geological Survey Open-File Report 2016-1090, 14 p., accessed April 1, 2017, at https://doi.org/10.3133/ofr20161090.

Bonisteel-Cormier, J.M., Nayegandhi, Amar, Wright, C.W., Brock, J.C., Nagle, D.B., Vivekanandan, Saisudha, Klipp, E.S., Fredericks, Xan, and Stevens, Sara, 2011, EAARL coastal topography-Assateague Island National Seashore, Maryland and Virginia, 2010: U.S. Geological Survey Data Series 628, 1 DVD. [Also available at https://pubs.usgs.gov/ds/628/.]

Buxton, H.T., Andersen, M.E., Focazio, M.J., Haines, J.W., Hainly, R.A., Hippe, D.J., and Sugarbaker, L.J., 2013, Meeting the science needs of the Nation in the wake of Hurricane Sandy-A U.S. Geological Survey science plan for support of restoration and recovery: U.S. Geological Survey Circular 1390, 26 p. [Also available at https://pubs.usgs.gov/circ/1390/.]

Doran, K.S., Stockdon, H.F., Sopkin, K.L., Thompson, D.M., and Plant, N.G., 2012, National assessment of hurricane-induced coastal erosion hazards-Mid-Atlantic Coast: U.S. Geological Survey Open-File Report 2013-1131, 28 p. [Also available at https://pubs.usgs.gov/of/2013/1131.]

Ganju, N.K., Suttles, S.E., Beudin, A., Nowacki, D. J., Miselis, J. L., and Andrews, B. D., 2016, Quantification of storm-induced bathymetric change in a back-barrier estuary: Estuaries and Coasts, v. 40, no. 1, p. 22-36. [Also available at https://doi.org/10.1007/s12237-016-0138-5.]

Gutierrez, B.T., Plant, N.G., and Thieler, E.R., 2011, A Bayesian network to predict the coastal vulnerability to sea-level rise: Journal of Geophysical Research, Earth Surface, v. 116, F02009, p. 1-15. [Also available at https://doi.org/10.1029/2010JF001891.]

Gutierrez, B.T., Plant, N.G., Thieler, E.R., and Turecek, A., 2015, Using a Bayesian network to predict barrier island geomorphologic characteristics: Journal of Geophysical Research, Earth Surface, v. 120, p. 1-24. [Also available at https://doi.org/10.1002/2015JF003671.]

Guy, K.K., 2015a, Barrier island shorelines extracted from Landsat imagery: U.S. Geological Survey Open-File Report 2015-1179, 3 p., accessed April 1, 2017, at https://doi.org/10.3133/ofr20151179. 
Guy, K.K., 2015b, Back-island and open-ocean shorelines, and sand areas of Assateague Island, Maryland and Virginia, April 12, 1989, to September 5, 2013: U.S. Geological Survey Data Series 928, accessed April 1, 2017, at https://doi.org/10.3133/ds928.

Guy, K.K., 2015c, Back-island and open-ocean shorelines, and sand areas of the undeveloped areas of New Jersey barrier islands, March 9, 1991, to July 30, 2013: U.S. Geological Survey Data Series 960, accessed April 1, 2017, at https://doi.org/10.3133/ds960.

Himmelstoss, E.A., Kratzmann, M., Hapke, C., Thieler, E.R., and List, J., 2010, The national assessment of shoreline change-A GIS compilation of vector shorelines and associated shoreline change data for the New England and Mid-Atlantic coasts: U.S. Geological Survey Open-File Report 2010-1119, accessed April 1, 2017, at https://pubs.usgs.gov/of/2010/1119.

La Selle, S.M., Lunghino, B.D., Jaffe, B.E., Gelfenbaum, G., and Costa, P.J.M., 2017, Hurricane Sandy washover deposits on Fire Island, New York: U.S. Geological Survey Open-File Report 2017-1014, 30 p., accessed April 1, 2017, at https://doi.org/10.3133/ofr20171014.

National Oceanic and Atmospheric Administration (NOAA), 2010, 2010 USACE NCMP Lidar-Atlantic Coast (NJ) point cloud files with orthometric vertical datum NAVD88 using GEOID12A, accessed April 1, 2017, at https:/coast.noaa.gov/htdata/lidar1_z/geoid12a/data/1133/.

National Oceanic and Atmospheric Administration (NOAA), 2016, NOAA Historical Surveys (T-Sheets): National Oceanic and Atmospheric Administration Shoreline Data web page, accessed April 1, 2017, at https://shoreline.noaa.gov/data/datasheets/t-sheets.html.

Norsys Software Corp, 2012, Netica 5.05, Bayesian network development software, accessed July 1, 2014, at https://www.norsys.com/.

Overbeck, J.R., Long, J.W., and Stockdon, H. F., 2017, Testing model parameters for wave-induced dune erosion using observations from Hurricane Sandy: Geophysical Research Letters, v. 44, p. 937-945. [Also available at https://doi.org/10.1002/2016GL071991.]

Plant, N.G., and Stockdon, H.F., 2012, Probalistic prediction of barrier-island response to hurricanes: American Geophysical Union, Journal of Geophysical Research; Earth Surface, v. 117, 17 p. [Also available at https://doi.org/10.1029/2011JF002326.]

Plant, N.G., Thieler, R.E., and Passeri, D.L., 2016, Coupling centennial-scale shoreline change to sealevel rise and coastal morphology in the Gulf of Mexico using a Bayesian network: Earth's Future, v. 4, p. 143-158. [Also available at https://doi.org/10.1002/2015EF000331.]

Smith, C.G., Osterman, L.E., and Poore, R.Z., 2013, An examination of historical inorganic sedimentation and organic matter accumulation in several marsh types within the Mobile Bay and Mobile-Tensaw River delta region: Journal of Coastal Research, Special Issue 63, p. 68-83.

Smith, C.G., and Osterman, L.E., 2014, An evaluation of temporal changes in sediment accumulation and impacts on carbon burial in Mobile Bay, Alabama, USA: Estuaries and Coasts, v. 37, p. 1092-1106.

Smith, C.G., Marot, M.E., Ellis, A.M., Wheaton, C.J., Bernier, J.C., and Adams, C.S., 2015, Sedimentological and radiochemical characteristics of marsh deposits from Assateague Island and the adjacent vicinity, Maryland and Virginia, following Hurricane Sandy: U.S. Geological Survey Open-File Report 2015-1169, accessed April 1, 2017, at https://doi.org/10.3133/ofr20151169.

Smith, K.E.L., Passeri, D.L. and Plant, N.G., 2017, Estuarine shoreline and sandline change model skill and predicted probabilities: U.S. Geological Survey data release, accessed April 1, 2017, at https://doi.org/10.5066/F7CZ35BC. 
Sopkin, K.L., Stockdon, H.F., Doran, K.S., Plant, N.G., Morgan, K.L.M., Guy, K.K., and Smith, K.E.L., 2014, Hurricane Sandy-Observations and analysis of coastal change: U.S. Geological Survey OpenFile Report 2014-1088, 54 p. [Also available at https://doi.org/10.3133/ofr20141088.]

Stockdon, H.F., Doran, K.J., Sopkin, K.L., Smith, K.E.L., and Fredericks, Xan, 2013, Coastal topography-Northeast Atlantic coast, post-Hurricane Sandy, 2012: U.S. Geological Survey Data Series 765, accessed April 1, 2017, at https://pubs.usgs.gov/ds/765/pubs765/.

Stockdon, H.F., Doran, K.J., Thompson, D.M., Sopkin, K.L., Plant, N.G., and Sallenger, A.H., 2012, National assessment of hurricane-induced coastal erosion hazards - Gulf of Mexico: U.S. Geological Survey Open-File Report 2012-1084, 51 p. [Also available at https://pubs.usgs.gov/of/2012/1084/. ]

Swiderski, D.C., Terrano, J.F., and Smith, K.E.L., 2016, Historical shoreline for New Jersey (1971 to 1978) — Vector digital data: U.S. Geological Survey data release, accessed April 1, 2017, at https://doi.org/10.5066/F76T0JR7.

Terrano, J.F., and Smith, K.E.L., 2015, Estuarine shoreline and barrier-island sandline change assessment: U.S. Geological Survey data release, accessed April 1, 2017, at https://doi.org/10.5066/F71Z42HN.

Thieler, E.R., Himmelstoss, E.A., Zichichi, J.L., and Ergul, Ayhan, 2008, Digital Shoreline Analysis System (DSAS) version 4.0-An ArcGIS extension for calculating shoreline change: U.S. Geological Survey Open-File Report 2008-1278. [Also available at https:/woodshole.er.usgs.gov/project-pages/ DSAS/version4/.]

U.S. Geological Survey, 2016a, USGS-CMG-COAWST model-Hurricane Sandy, USE31 5km Nest: U.S. Geological Survey web page, accessed April 1, 2017, at https://cmgdata.usgsportals.net/\#modulemetadata/909a3a78-a1f2-3cfb-bd47-0f79a508275b/ed35286b-4370-4693-915f-7133c418c6e9, and URL reference updated September 27, 2017, to https://cmgdata.usgsportals.net/\#module-metadata/fbdd419bf297-49e6-b6e1-a74dc01b8010/0123d42a-0204-4091-8998-d959e40b970c.

U.S. Geological Survey, 2016b, Coastal Change Hazards Portal, Version 1.1.46: U.S. Geological Survey web page, accessed April 1, 2017, at https://marine.usgs.gov/coastalchangehazardsportal/.

U.S. Geological Survey, 2016c, USGS Chincoteague Bay model for Hurricane Sandy, Oceanographic Model and Data Portal: U.S. Geological Survey web page, accessed April 1, 2017, at https:/cmgdata. usgsportals.net/\#module-metadata/8f67ee68d-07c69-63bf65-ba24-fa67ad68b63a68a/63fae63fb65-34514122-3993f-da3456f3417b0737d and URL reference updated 27 September, 2017 to https://cmgdata.usgsportals.net/\#modulemetadata/8f67ee8d-07c9-3bf5-ba24-fa7ad8b3a68a/3fae3fb5-3451-4122-993f-da6f17b0737d.

U.S. Geological Survey, 2016d, USGS Barnegat Bay Model for Hurricane Sandy-run076, Oceanographic Model and Data Portal: U.S. Geological Survey web page, accessed April 1, 2017, at https://cmgdata. usgsportals.net/\#module-metadata/0d0bc16b-90f10-3976-ae3974a-9906a750497e/753956a750418c750495a750439-750440ad-ac750497f-722022be750464c750421

and URL updated 27 September, 2017 to https:/cmgdata.usgsportals.net/\#module-metadata/0d0bc16b90f0-3976-ae4a-9906a750497e/138239f2-c112-448e-8961-5c81b4f915bb .

Wright, C.W., Fredericks, Xan, Troche, R.J., Klipp, E.S., Kranenburg, C.J., and Nagle, D.B., 2014, EAARL-B coastal topography_Eastern New Jersey, Hurricane Sandy, 2012; first surface (version 1.1, August 18, 2014): U.S. Geological Survey Data Series 767, accessed April 1, 2017, at https://doi.org/10.3133/ds767.

Zambon, J.B., He, Ruoying, and Warner, J.C., 2014, Tropical to extratropical-Marine environmental changes associated with Superstorm Sandy prior to its landfall: Geophysical Research Letters, v. 41, p. 8935-8943. [Also available at https://doi.org/10.1002/2014GL061357.] 
Zaremba, N.J., Smith, C.G., Bernier, J.C., and Forde, A.S., 2016a, Application of ground penetrating radar for identification of washover deposits and other stratigraphic features-Assateague Island, MD: Journal of Environmental and Engineering Geophysics, v. 21, p. 173-186, accessed April 1, 2017, at https://doi. org/10.2113/JEEG21.4.173.

Zaremba, N.J., Smith, K.E.L., Bishop, J.M., and Smith, C.G., 2016b, Ground-penetrating radar and differential global positioning system data collected from Long Beach Island, New Jersey, April 2015: U.S. Geological Survey Data Series 1006, accessed April 1, 2017, at https://doi.org/10.3133/ds1006. 


\section{Appendix 1. BN Models}

This appendix contains a text-formatted version of the Bayesian network $(\mathrm{BN})$ models that can be saved in a file with .dne file extension and opened with Netica (Norsys Software Corp, 2012). The data from Terrano and Smith (2015) can be used to train and run the BN using Netica software and application interfaces.

\section{Shoreline Change}

// File created by PlantN at USGS using Netica 5.05 on Oct 14, 2016 at $16: 41: 54$.

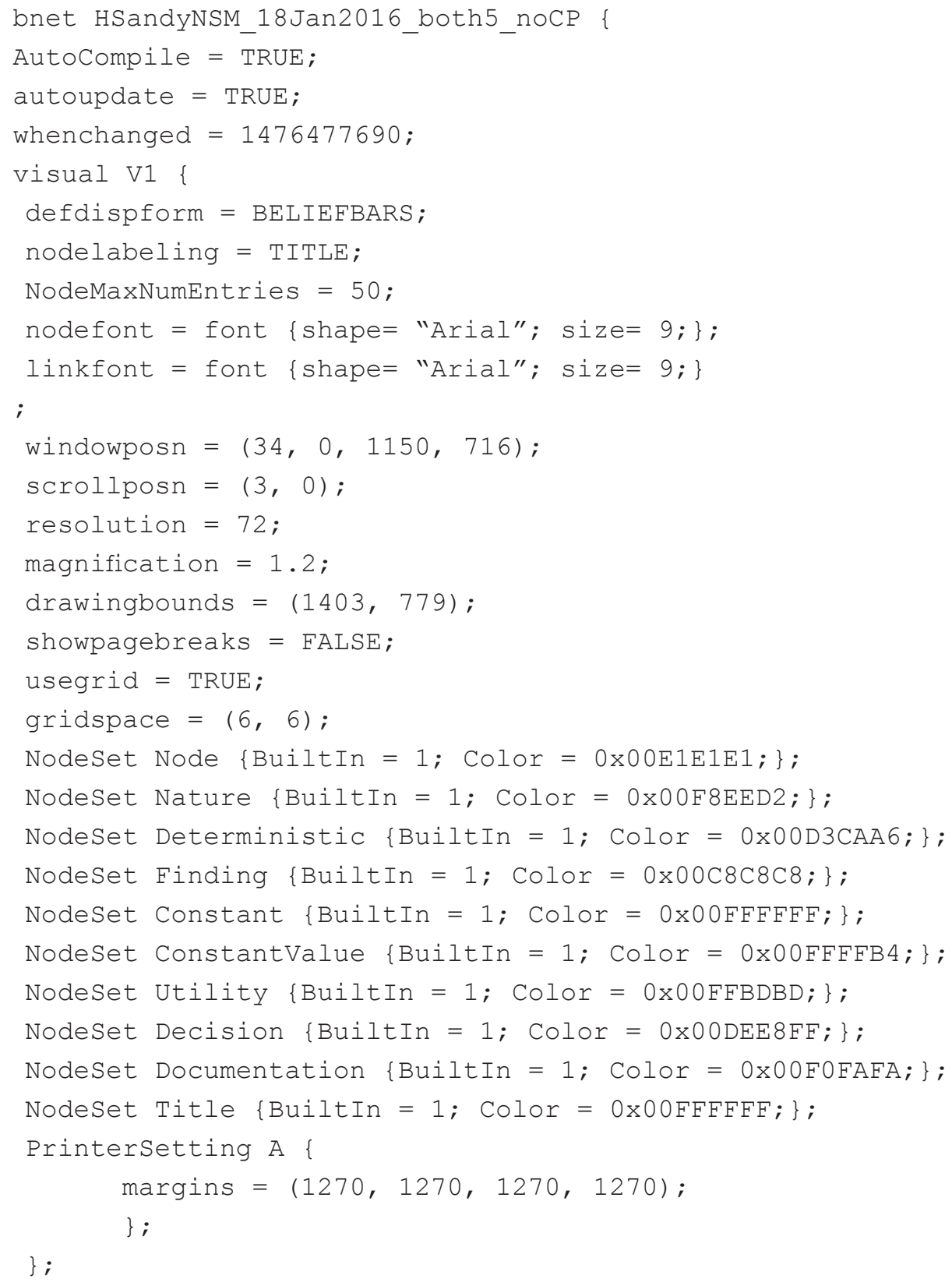




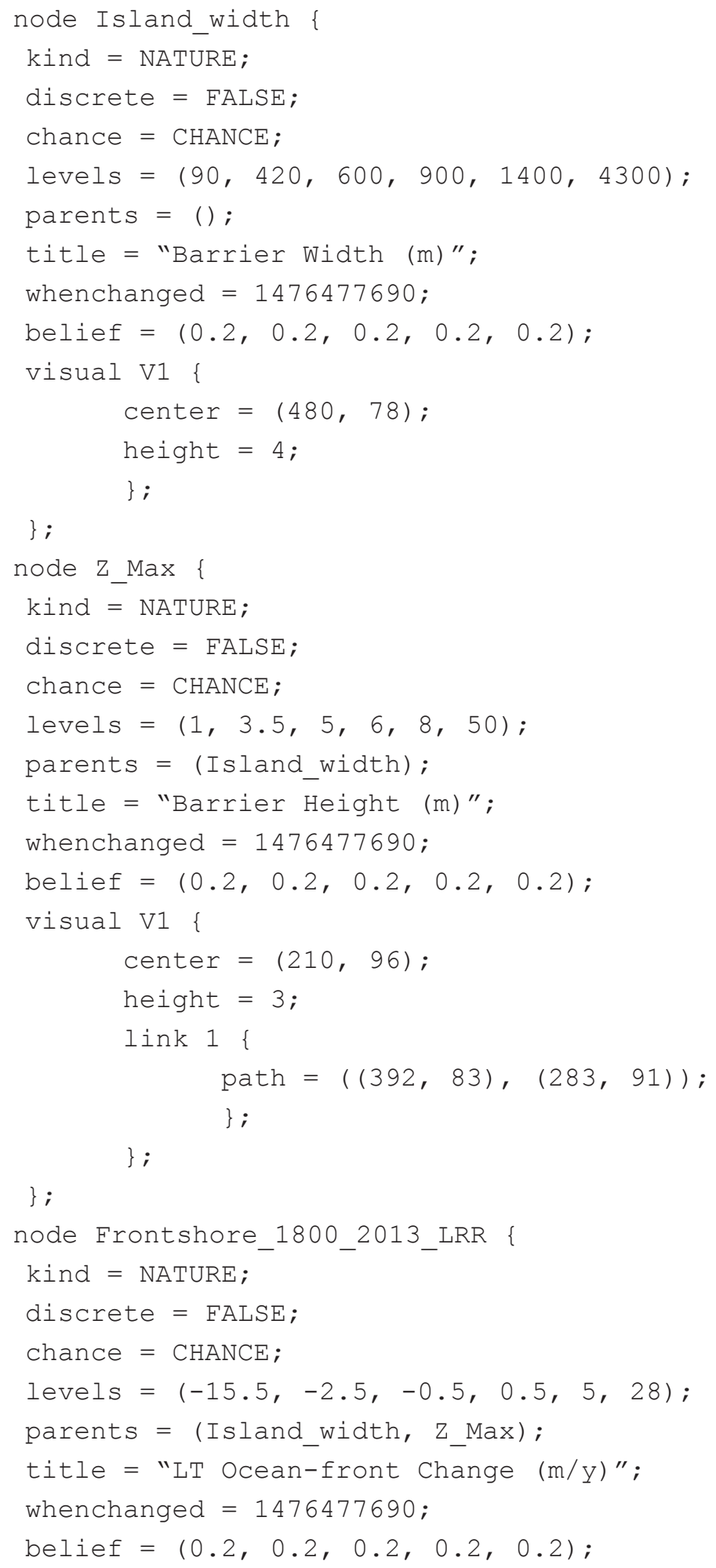




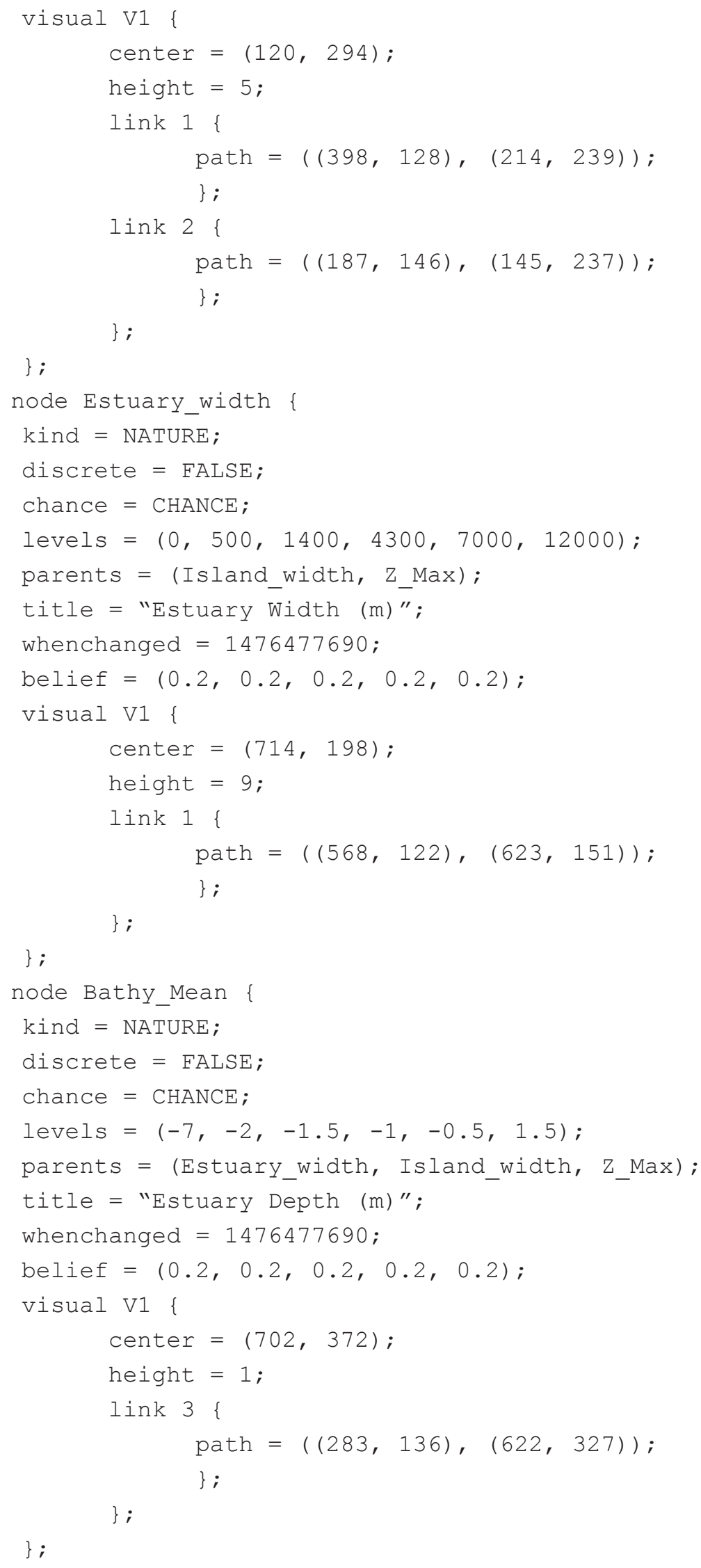




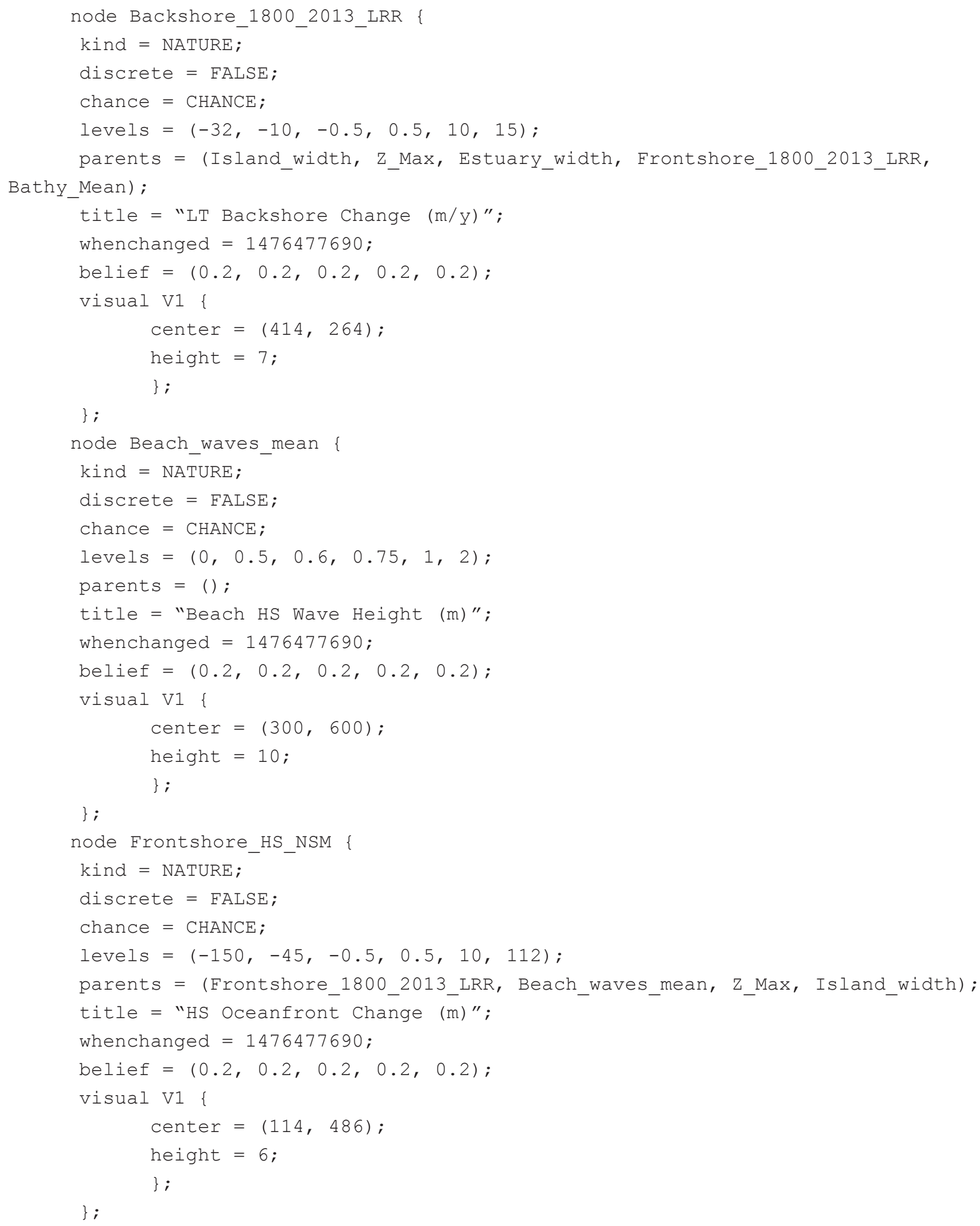




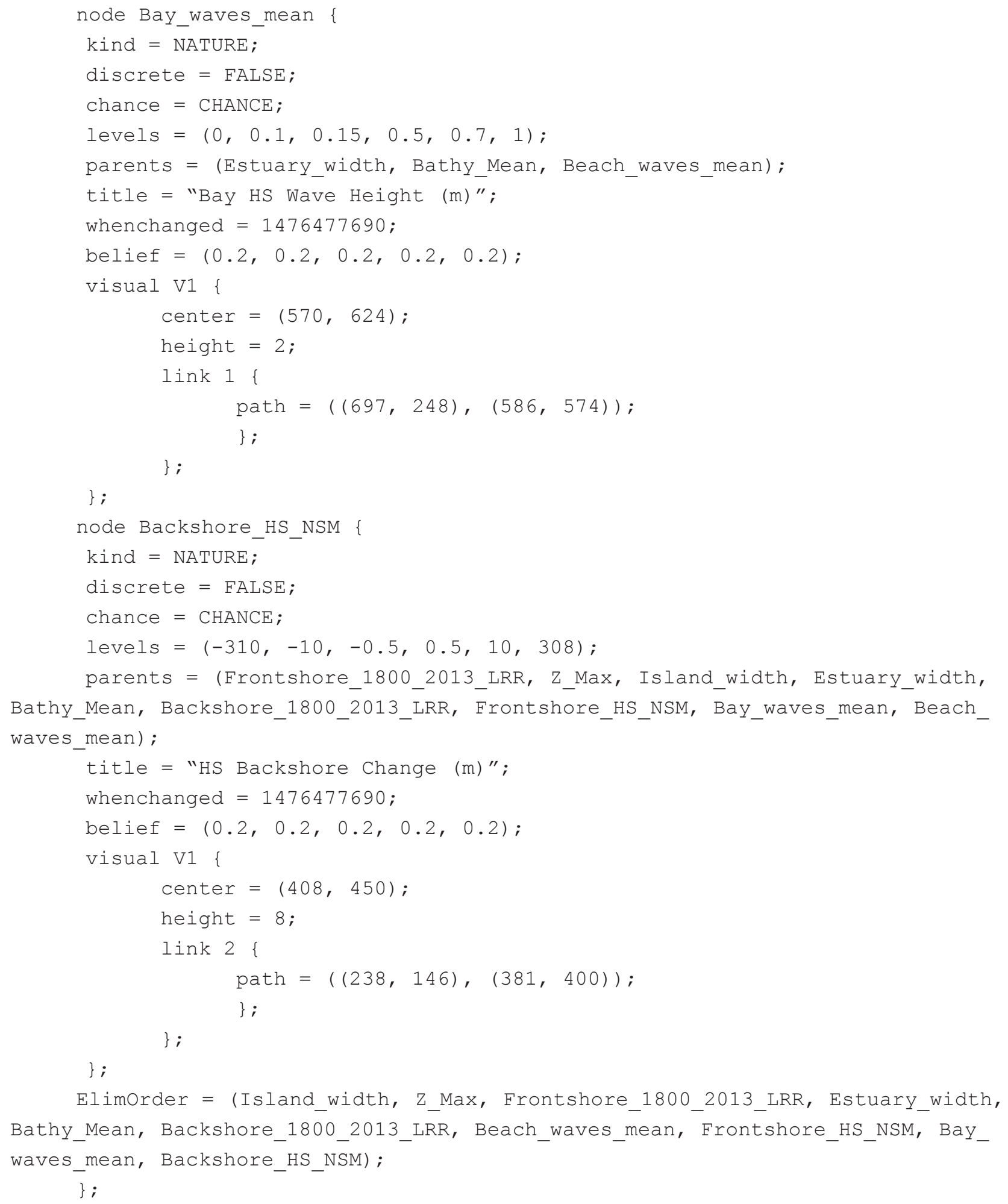




\section{Sandline, Long-Term}

// File created by PlantN at USGS using Netica 5.05 on Nov 30, 2016 at $15: 18: 03$.

bnet wetlandPhysicalchange_LT_Sandl \{

AutoCompile = TRUE;

autoupdate $=$ TRUE;

whenchanged $=1480537083$;

visual V1 \{

defdispform = BELIEFBARS;

nodelabeling = TITLE;

NodeMaxNumEntries $=50$;

nodefont $=$ font $\{$ shape= "Arial"; size= 9; $;$;

linkfont $=$ font $\{$ shape= "Arial"; size= 9; ;

windowposn $=(8,5,1397,674)$;

resolution $=72$;

magnification $=1.41421$;

drawingbounds $=(1403,786)$;

showpagebreaks = FALSE;

usegrid = TRUE;

gridspace $=(6,6)$;

NodeSet Node $\{$ BuiltIn $=1$; Color $=0 \times 00 \mathrm{E} 1 \mathrm{E} 1 \mathrm{E} 1 ;\}$;

Nodeset Nature $\{$ BuiltIn $=1$; Color $=0 \times 00$ F8EED $2 ;\}$;

Nodeset Deterministic $\{$ BuiltIn $=1$; Color $=0 \times 00$ D3CAA 6 ; ;

Nodeset Finding $\{$ BuiltIn $=1$; Color $=0 \times 00 \mathrm{C} 8 \mathrm{C} 8 \mathrm{C} 8$; ;

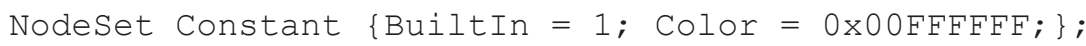

Nodeset ConstantValue $\{$ BuiltIn $=1$; Color $=0 \times 00 F F F F B 4 ;$;

Nodeset Utility $\{$ BuiltIn $=1$; Color $=0 \times 00 \mathrm{FFBDBD} ;\}$;

Nodeset Decision $\{$ BuiltIn $=1$; Color $=0$ x00DEE8FF; ;

Nodeset Documentation $\{$ BuiltIn $=1$; Color $=0 \times 00 F 0 F A F A ;$;

NodeSet Title $\{$ BuiltIn $=1$; Color $=0 x 00 \mathrm{FFFFFF} ;\}$;

Printersetting A \{ margins $=(1270,1270,1270,1270) ;$

\} ;

\};

node Island_width \{

kind = NATURE;

discrete $=$ FALSE;

chance $=$ CHANCE;

levels $=(0,750,1500,4300)$;

parents $=()$;

title = "Barrier Width (m)";

whenchanged = 1480537071;

belief $=(0.3333333,0.3333333,0.3333333)$;

visual V1 \{ 


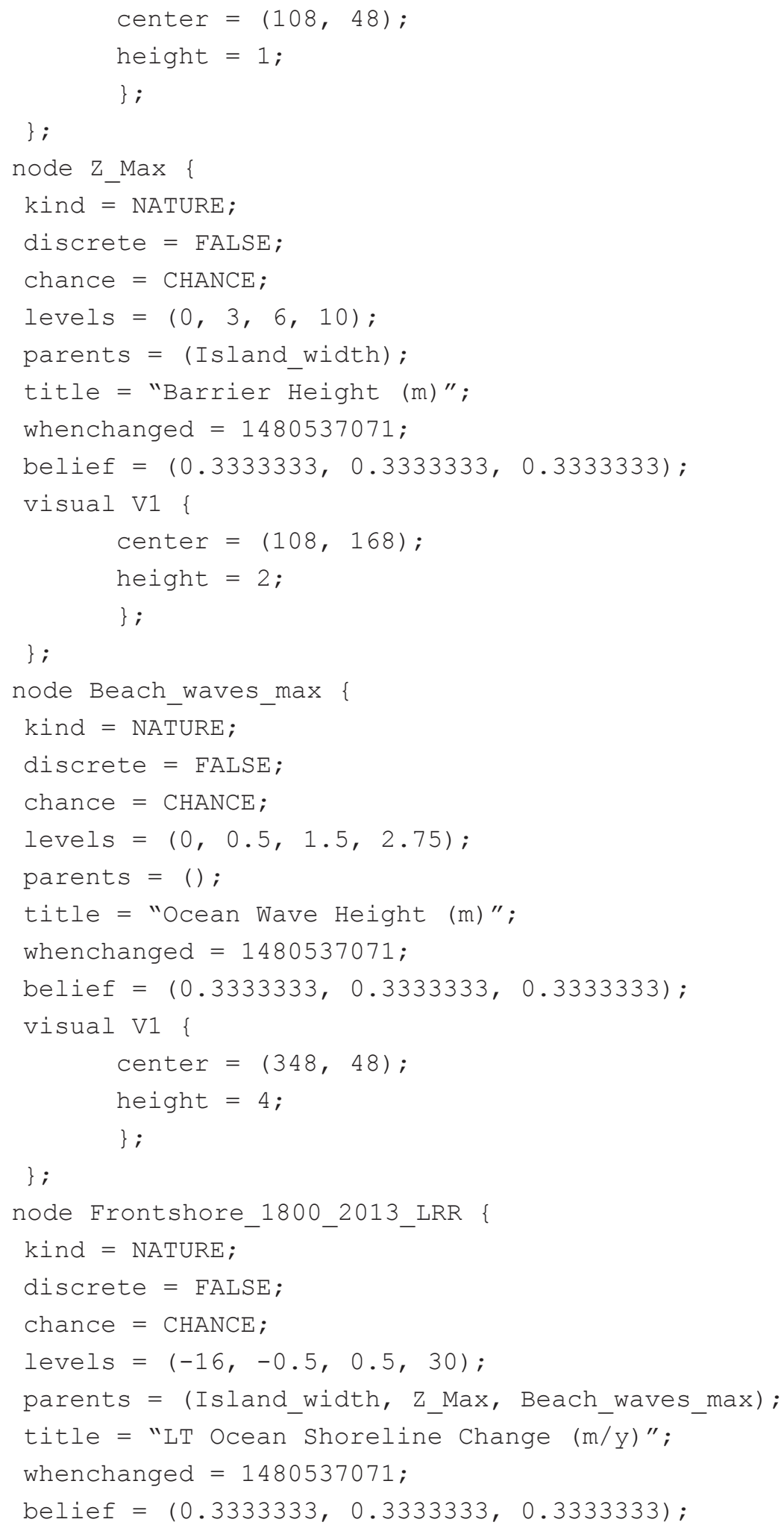




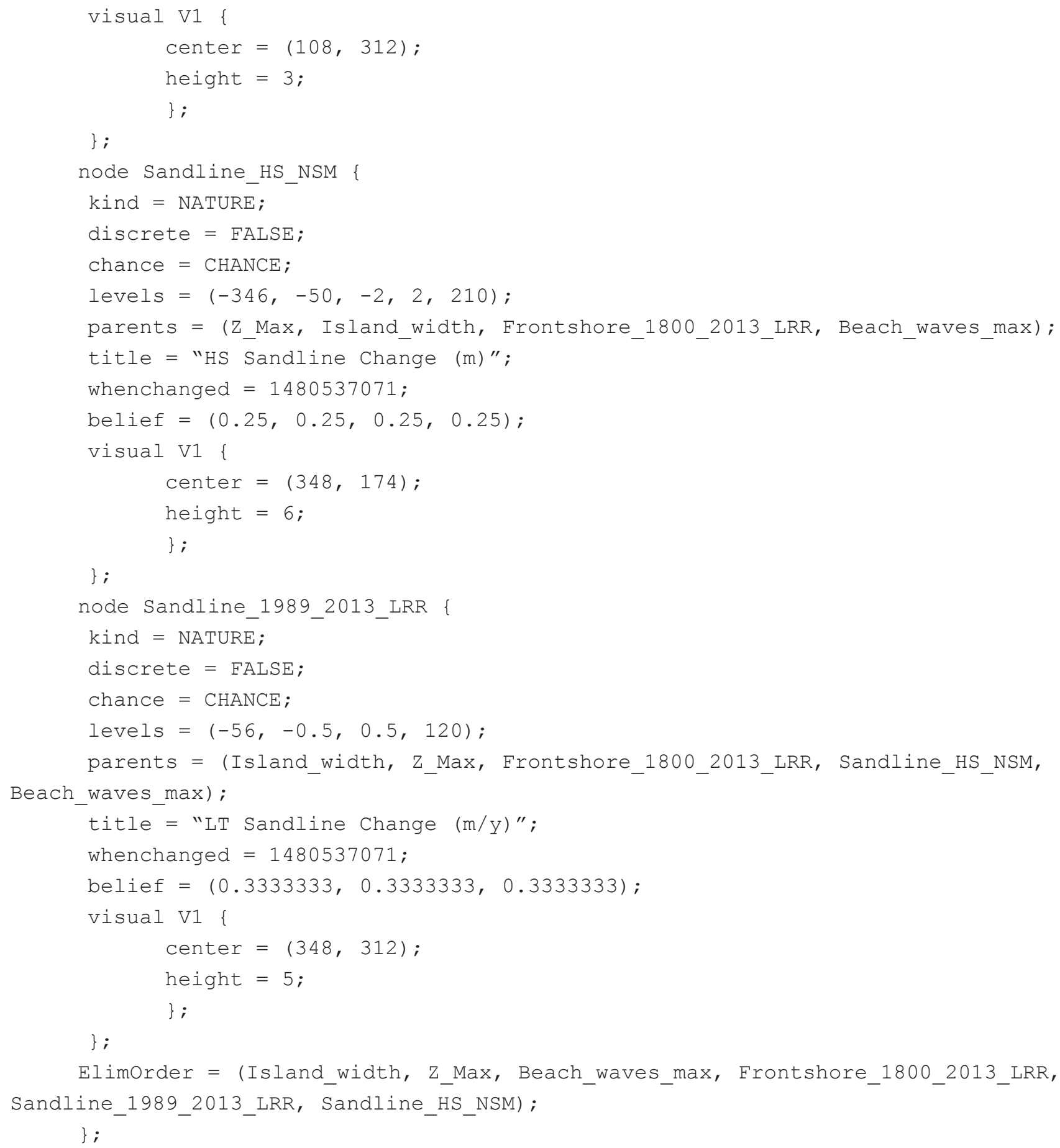




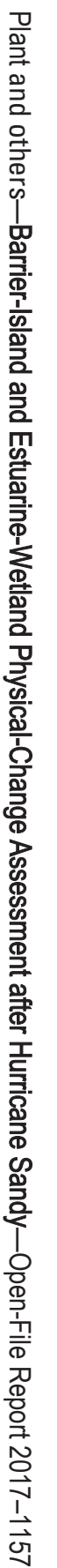

